\title{
Rate and synchronicity of environmental changes on a shallow carbonate platform (Late Oxfordian, Swiss Jura Mountains)
}

\author{
ANDRÉ STRASSER*, STÉPHANIE VÉDRINE† and NOÉMIE STIENNE \\ *Department of Geosciences, University of Fribourg, Chemin du Musée 6, 1700 Fribourg, Switzerland \\ (E-mail: andreas.strasser@unifr.ch) \\ $\uparrow$ BRGM Geology Division - Geology of Sedimentary Basins, 3 avenue Claude Guillemin, 45060 Orléans \\ Cedex 02, France \\ $\$$ Department of Environmental and Geographical Sciences, Manchester Metropolitan University, \\ Chester Street, Manchester M1 5GD, UK
}

\begin{abstract}
Recent global change occurs within decades and leaves a significant imprint on shallow carbonate platforms. To what extent can rate and synchronicity of environmental changes in the past be evaluated in order to allow comparisons with the processes and products of today? Sections of a carbonate-dominated platform of Late Oxfordian age have been logged in detail in the Swiss Jura Mountains. The time frame, based on ammonite biostratigraphy and the hierarchical stacking of the sedimentary sequences, suggests that these formed by low-amplitude, high-frequency sea-level changes in tune with the orbital cycles. The smallest unit, the elementary sequence, can thus be attributed to the $20 \mathrm{kyr}$ precession cycle. By identifying sequence-stratigraphic elements such as maximum-flooding surfaces within an elementary sequence, an even higher time resolution can be obtained and reconstructions of changes in water depth and sea-level are attempted. Sedimentation rates were highly irregular and discontinuity surfaces are common. Correlation of such surfaces from one section to the other is tentative because they could also have formed locally and are not necessarily synchronous. On the scale of elementary sequences, the vertical facies evolution permits interpretation of changes in water depth, which were produced by eustatic sea-level changes (allocyclic) and/or by autocyclic processes. The distribution of clay minerals indicates changes of sea-level, as well as of rainfall in the hinterland. Biotic changes were controlled by water depth and water quality, and also by nutrient and clay input. Carbon and oxygen isotopes do not show significant shifts within the elementary sequences. The original ecological, mineralogical and geochemical signals have partly been homogenized because of time-averaging through bioturbation and through reworking by storms, and because of diagenetic modifications. Consequently, there is potential to interpret environmental changes on the studied carbonate platform but the time resolution is not better than a few thousand years. The rates and the synchronicity of the processes leading to the observed environmental changes can thus be estimated only within this time frame.
\end{abstract}

Keywords Carbonate platform, cyclostratigraphy, environmental change, Oxfordian, Swiss Jura. 


\section{INTRODUCTION}

The global change which was experienced over the last century occurred at very high rates: atmospheric $\mathrm{CO}_{2}$ increased by about 80 p.p.m.; this and the increase of other greenhouse gases forced global mean temperature to rise by $1^{\circ} \mathrm{C}$, and global mean sea-level has risen by $17 \mathrm{~cm}$ through thermal expansion of the ocean water and melting of land-locked ice (IPCC, 2007). In addition to greenhouse gases, changes in solar irradiance and volcanic aerosols influence the climate system on decadal to centennial scales (Crowley, 2000; Servonnat et al., 2010). These rapid changes have a significant impact on ecosystems on land and in the sea and, of course, also affect shallow-water carbonate platforms. Corals as important carbonate producers are particularly sensitive: increased water temperature leads to bleaching (Peñaflor et al., 2009); acidification of the ocean water results in reduced carbonate production (Jokiel et al., 2008); increased storm intensity leads to damage on coral reefs (Emanuel, 2005); and increased nutrient input due to heavy rains in the hinterland favours macroalgae that hamper coral growth (McCook, 1999). The century-scale trends are punctuated by extreme events such as the El Niño - Southern Oscillation phenomenon, which may cause short-term temperature peaks that result in the mass bleaching of corals. Some organisms are resilient enough to recover, others will die (Smith et al., 2008; Brandt, 2009). The ecological niches thus liberated will quickly be filled by organisms adapted to the new environmental conditions.

The carbonate platforms of today are perfect recorders of many aspects of global change, and the recent sedimentary record can be studied with a yearly to daily time resolution. Furthermore, the record can be compared with instrumental measurements of climate and oceanographic parameters. For example, analyses of growth bands in corals permit reconstruction of changes in water temperature and metabolism (Bessat \& Buigues, 2001), or tempestites can be dated and correlated based on monitoring of the storm tracks (Goff et al., 2010).

When dealing with carbonate platforms in the geological past, this high precision in dating and correlation is not possible. Banding in fossil corals, tidal bundles or varves may open short time windows but these are localized and impossible to precisely correlate at a global scale. The best time resolution so far available for the analysis of ancient carbonate platforms is given by orbital (Milankovitch) cyclicity. If it can be shown that the orbital cycles are recorded faithfully in the sediment, then a time resolution of $20 \mathrm{kyr}$ becomes possible (corresponding to the precession of the equinoxes; Berger et al., 1989; Strasser et al., 2006). However, even if a cyclostratigraphical time frame can be established, there is still a huge discrepancy between the monitoring of the recent global change at a decadal to centennial scale and the potential for studying past global changes with a time resolution of several thousand years.

This paper presents an analysis of environmental changes recorded in the sedimentary record on a carbonate-dominated platform that today is found in the Swiss and French Jura Mountains, focussing on a time interval of $170 \mathrm{kyr}$ situated in the Late Oxfordian (Late Jurassic). Based on detailed logging of vertical sections and on facies analysis, sedimentary sequences are defined according to sequence-stratigraphic and cyclostratigraphic concepts. Sea-level fluctuations are discussed, as are terrigenous input, carbon and oxygen isotopes and biotic changes within $20 \mathrm{kyr}$ sequences in an effort to interpret the environmental changes that affected the Jura platform. The interpretations are regional because the available chronostratigraphic framework is too coarse to allow for the correlation of rapid changes on a global scale. An attempt is made to find answers to the following questions:

1 What is the highest time resolution that can be obtained on ancient carbonate platforms?

2 To what extent is it possible to correlate the sedimentary record of environmental changes on a regional scale?

3 To what extent can rate and synchronicity of environmental changes of the past be estimated and serve as examples of consequences of today's global change?

Although this study concerns only a short time window in the long history of planet Earth, and although it is limited to shallow-water carbonates, it nevertheless emphasizes the complexity of the interlinked processes that acted and still act in the sedimentary environments.

\section{PALAEOGEOGRAPHIC, STRATIGRAPHIC AND PALAEOCLIMATOLOGICAL SETTING}

In Late Jurassic times, today's Jura Mountains were part of a shallow platform extending 
between the Paris Basin to the west, the Tethys Ocean to the south-east, and the London-Brabant, Rhenish and Bohemian massifs of Hercynian origin to the north (Fig. 1). Palaeolatitude was ca 26 to $27^{\circ} \mathrm{N}$ (Dercourt et al., 1993). The platform was morphologically structured by synsedimentary reactivation of basement faults and epicontinental basins developed mainly to the south of the platform (Allenbach, 2001).

The lithostratigraphy of the Oxfordian of the Swiss Jura has been established by Gygi (1995, 2000). The chronostratigraphic position of the formations and members is given by ammonite biostratigraphy (at the subzone level) and by mineralogical and stratigraphic correlations (Gygi \& Persoz, 1986; Gygi, 1995, 2000). In addition, Gygi et al. (1998) identified large-scale sequence boundaries, which correlate well with those recognized by Hardenbol et al. (1998) in several European basins (Fig. 2). A cyclostratigraphic time scale for the Oxfordian and Kimmerdigian has been proposed by Strasser (2007), compiling the information from 19 platform sections and including four basinal sections in south-eastern France, where good biostratigraphic control is offered by ammonites (Fig. 3).

Lagoonal facies rich in carbonate-producing organisms, coral patch-reefs and ooid shoals suggest warm, subtropical waters. Water depths varied between a few tens of metres in the open lagoons to intertidal and supratidal along the coasts of low-lying islands. Siliciclastics originating from the Hercynian massifs were periodically shed onto the platform and into the basins (Gygi \& Persoz, 1986; Pittet, 1996), implying humid conditions in the hinterland. In Fig. 3, the trends in

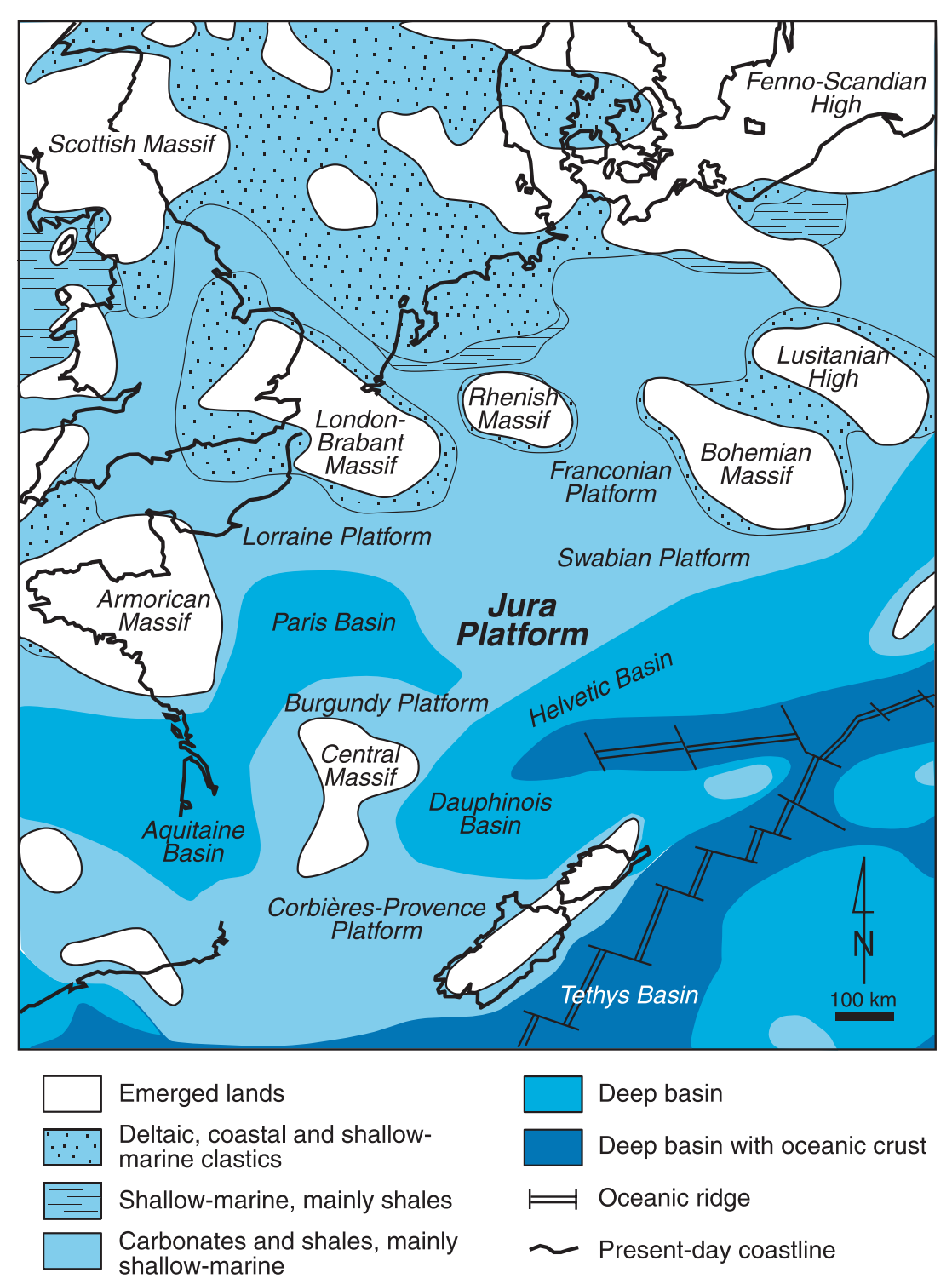

Fig. 1. Palaeogeographic setting of the Jura platform during the Oxfordian. Modified from Carpentier et al. (2006), based on Enay et al. (1980), Ziegler (1990) and Thierry. (2000). 


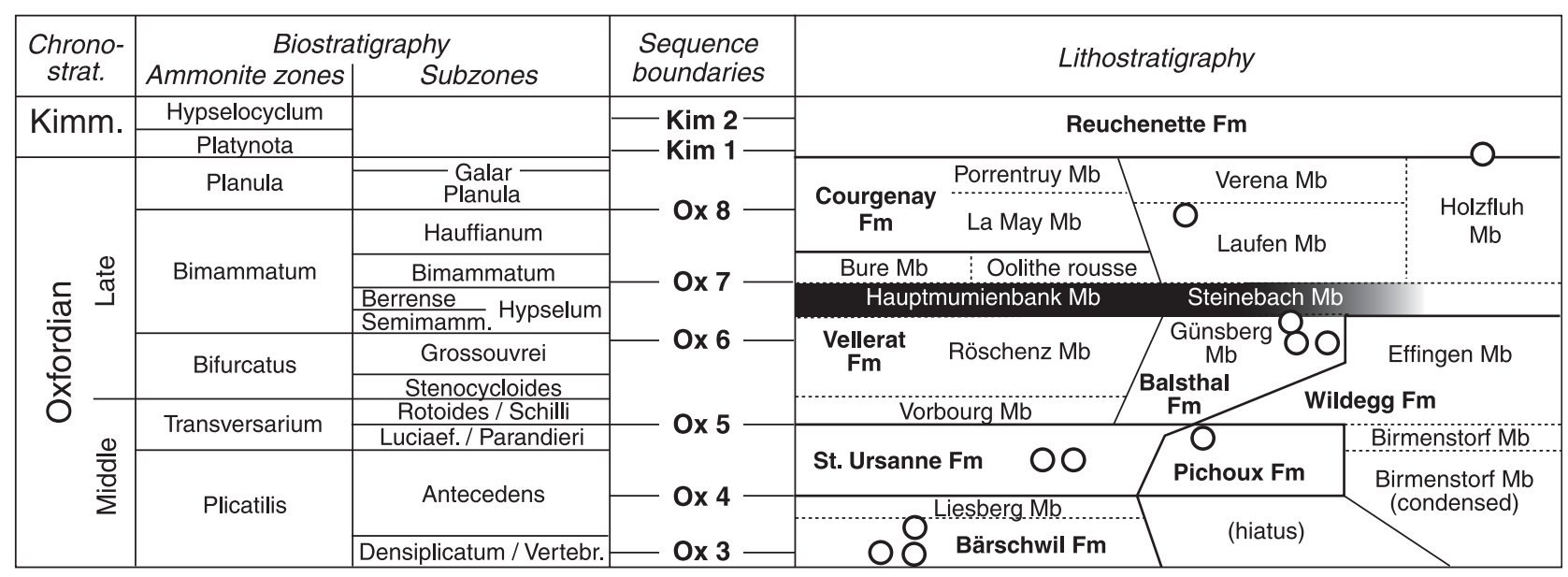

Fig. 2. Stratigraphic scheme of the Middle to Late Oxfordian. The Hauptmumienbank and Steinebach Members are highlighted. Lithostratigraphy and biostratigraphy after Gygi (1995, 2000), with circles indicating where biostratigraphically significant ammonites have been found. Sequence boundaries according to Hardenbol et al. (1998) and Gygi et al. (1998). Fm, formation; Mb, member.

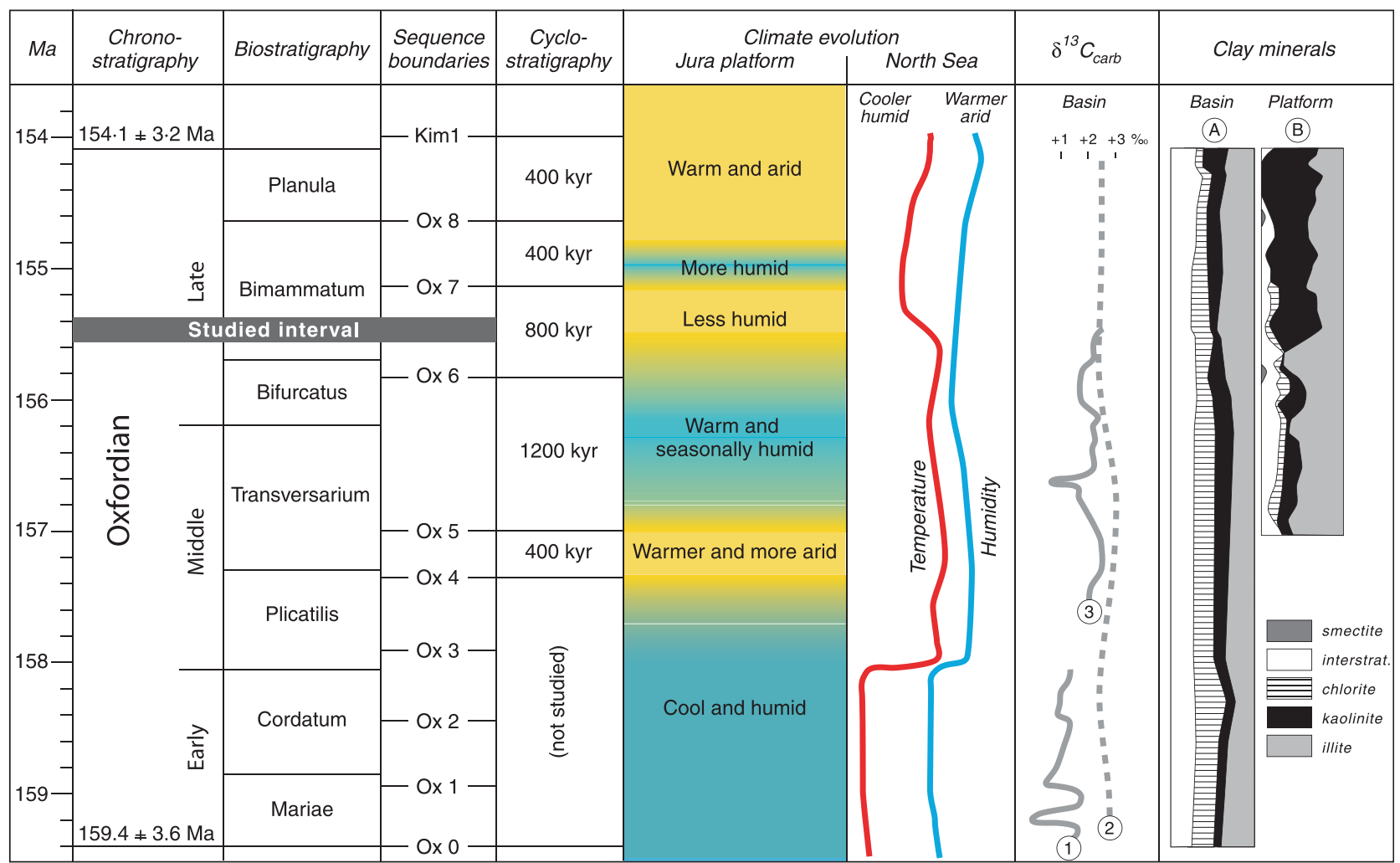

Fig. 3. Climate evolution of the Jura platform compared with published information: climate trends from the southern North Sea (Abbink et al., 2001); carbon-isotope curves from: (1) Louis-Schmid (2006); (2) Bartolini et al. (1996); and (3) Padden et al. (2001). Clay-mineral assemblages according to: (A) Deconinck et al. (1985); and (B) Gygi \& Persoz (1986). Chronostratigraphy, biostratigraphy and sequence stratigraphy according to Hardenbol et al. (1998), cyclostratigraphy from Strasser (2007). For explanation see text.

climate evolution are indicated for the Swiss Jura (data from Pittet, 1996; Hug, 2003). These trends are compared with those proposed by Abbink et al. (2001) for the southern North Sea, based on palynological analyses. The studied interval sits at the transition between a warm, seasonally humid to less humid climate ruling on the Jura platform, while the North Sea record suggests a change from warmer to cooler temperatures. Carbon-isotope curves measured in Swiss and French platform 
and hemipelagic sections display important negative shifts in the early and middle Oxfordian that have been attributed to methane release (Padden et al., 2001), and positive shifts that are related to plate-tectonic activity (Louis-Schmid et al., 2007). For the studied time interval, however, the curve available from the Umbria-Marche basin in Italy is stable (Bartolini et al., 1996). Clay-mineral assemblages measured in the hemipelagic sediments of the sub-Alpine basin in France show a relatively stable distribution throughout the Oxfordian (Deconinck et al., 1985), while on the Jura platform they display a more complex pattern (Gygi \& Persoz, 1986).

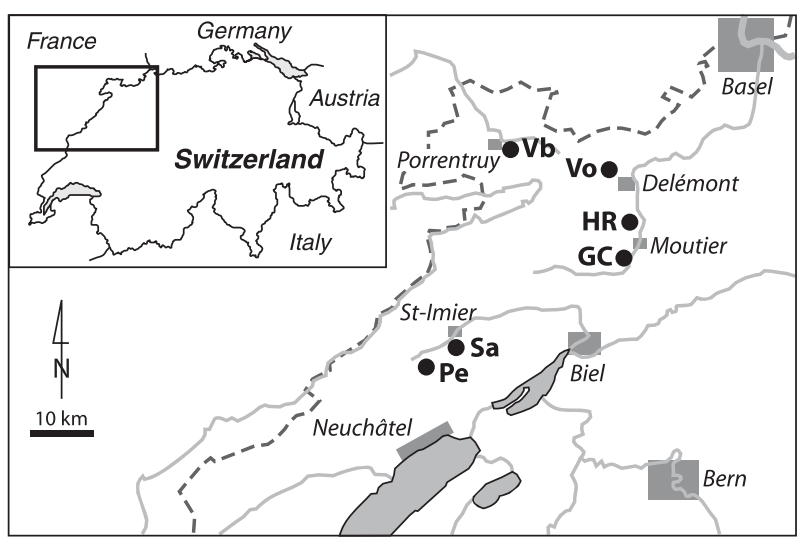

Fig. 4. Geographical location of the studied sections in north-western Switzerland. Pe, Pertuis; Sa, Savagnières; GC, Gorges de Court; HR, Hautes-Roches; Vo, Vorbourg; Vb, Voyeboeuf.

\section{MATERIAL AND METHODS}

For this study, six sections are presented that have been logged at centimetre-scale and densely sampled by Védrine (2007): Pertuis, Savagnières, Gorges de Court, Hautes-Roches, Vorbourg and Voyeboeuf (Fig. 4; Table 1). Furthermore, parts of the Hautes-Roches and Vorbourg sections have been analysed with a 100\% sample cover by Stienne (2010). Thin sections, polished slabs and marl washings have been prepared. Where no samples were taken, the facies have been determined on the outcrop with a hand lens. Under the petrographic microscope or the binocular magnifier, microfacies have been analysed using the Dunham (1962) classification and a semi-quantitative estimation of the abundance of rock constituents. Special attention has been paid to sedimentary structures and to omission surfaces (Clari et al., 1995; Hillgärtner, 1998). The sum of this sedimentological information is then used to interpret the depositional environments. For the sequence-stratigraphic interpretation, the nomenclature of Vail et al. (1991) is applied. The high-resolution sequence-stratigraphic and cyclostratigraphic interpretations follow the concepts of Strasser et al. (1999): sedimentary sequences that formed through high-frequency, low-amplitude sea-level changes in tune with the orbital cycles are interpreted with the sequence-stratigraphic approach.

Table 1. Location, stratigraphic range and authors of sections used in this study. Co-ordinates refer to the Swiss national topographic map 1:25000.

\begin{tabular}{|c|c|c|c|c|c|}
\hline Code & Name & Location & $\begin{array}{l}\text { Co-ordinates at } \\
\text { base of section }\end{array}$ & $\begin{array}{l}\text { Stratigraphic } \\
\text { interval }\end{array}$ & Authors \\
\hline$\overline{\mathrm{Pe}}$ & Pertuis & $\begin{array}{l}\text { Along the road from } \\
\text { Dombresson to Pertuis }\end{array}$ & $561^{\prime} 850 / 216^{\prime} 050$ & $\begin{array}{l}\text { Middle to } \\
\text { Late Oxfordian }\end{array}$ & $\begin{array}{l}\text { Pittet (1996) } \\
\text { Védrine (2007) }\end{array}$ \\
\hline Sa & Savagnières & $\begin{array}{l}\text { Along the road between } \\
\text { St-Imier and Val-de-Ruz }\end{array}$ & $566^{\prime} 750 / 219^{\prime} 750$ & $\begin{array}{l}\text { Middle to } \\
\text { Late Oxfordian }\end{array}$ & $\begin{array}{l}\text { Pittet (1996) } \\
\text { Védrine (2007) }\end{array}$ \\
\hline GC & Gorges de Court & $\begin{array}{l}\text { Along the road between } \\
\text { Moutier and Court }\end{array}$ & $593^{\prime} 200 / 234^{\prime} 300$ & $\begin{array}{l}\text { Middle to } \\
\text { Late Oxfordian }\end{array}$ & $\begin{array}{l}\text { Pittet (1996) } \\
\text { Hug (2003) } \\
\text { Védrine (2007) }\end{array}$ \\
\hline HR & Hautes-Roches & $\begin{array}{l}\text { Along the forest path } \\
\text { south of the village of } \\
\text { Hautes-Roches }\end{array}$ & $594^{\prime} 950 / 238^{\prime} 250$ & $\begin{array}{l}\text { Middle to } \\
\text { Late Oxfordian }\end{array}$ & $\begin{array}{l}\text { Pittet (1996) } \\
\text { Dupraz (1999) } \\
\text { Védrine (2007) } \\
\text { Stienne (2010) }\end{array}$ \\
\hline Vo & Vorbourg & $\begin{array}{l}\text { Along the road above } \\
\text { Vorbourg chapel }\end{array}$ & $593^{\prime} 850 / 247^{\prime} 625$ & $\begin{array}{l}\text { Middle to } \\
\text { Late Oxfordian }\end{array}$ & $\begin{array}{l}\text { Pittet (1996) } \\
\text { Védrine (2007) } \\
\text { Stienne (2010) }\end{array}$ \\
\hline $\mathrm{Vb}$ & Voyeboeuf & $\begin{array}{l}\text { Along the road between } \\
\text { Porrentruy and Courgenay }\end{array}$ & $574^{\prime} 160 / 251^{\prime} 120$ & Late Oxfordian & Védrine (2007) \\
\hline
\end{tabular}


Clay minerals have been analysed for the Savagnières section (Védrine, 2007). Sample preparation and X-ray diffraction were carried out at the Institute of Geology of the University of Neuchâtel (Switzerland) on a Scintag XRD 2000 diffractometer (Scintag Inc., Cupertino, CA, USA). Sample preparation was based on the methods described by Kübler (1990). The intensities of the peaks that characterize each clay mineral (smectite, chlorite, illite, kaolinite and interstratified) are measured in counts per second (cps) for the semi-quantitative estimation of the proportion of clay minerals, which is given in relative percent without correction factors. Variations of more than $10 \%$ are considered as significant. Quartz content has been estimated from thin sections and from X-ray diffraction analyses of bulk-rock in percent, or from the 2 to $16 \mu \mathrm{m}$ fraction in cps when the total amount of quartz in bulk was not sufficient. The illite crystallinity index is expressed as the ratio of the width of the (001) basal peak at mid-height to the peak height above background measured on $<2 \mu \mathrm{m}$ fraction diffractograms.

Oxygen $\left(\delta^{18} \mathrm{O}\right)$ and carbon $\left(\delta^{13} \mathrm{C}\right)$ isotope analyses of the Vorbourg and Savagnières sections have been performed on whole-rock samples, preferentially selecting micritic intervals representing carbonate mud where organic and inorganic sources have been homogenized (Védrine, 2007). The measurements were carried out at the University of Lausanne (Switzerland) using a Finnigan Delta Plus XL mass spectrometer (Thermo Fisher Scientific, Waltham, MA, USA) with an attached GasBench II and a PAL autosampler (Thermo Fisher Scientific). Rock powders were reacted with $100 \%$ phosphoric acid at $90^{\circ} \mathrm{C}$. During continuous $\mathrm{CO}_{2}$ gas flow, 10 measurements were made for each sample. The obtained raw results were corrected regularly by comparison to an internal standard (Carrara Marble), which is calibrated to National Bureau of Standards (NBS) 19. The mean value of the 10 corrected raw results is calculated and represents the $\mathrm{C}$ and $\mathrm{O}$ isotope values for a given sample. The error margins include the measurement and reproducibility error and are less than $\pm 0 \cdot 1 \%$.

\section{DEPOSITIONAL SEQUENCES}

For the purpose of this paper, the interval around sequence boundary Ox6 has been chosen (Fig. 5). This boundary is placed in the upper part of the Bifurcatus ammonite zone (Gygi et al., 1998; Fig. 2). In the studied sections, plant remains, microbial mats with birdseyes or low-energy lagoonal sediments indicate the relatively shallowest facies in a succession that includes coral reefs, oolite shoals and oncoid-rich lagoons. According to the sequence-chronostratigraphic chart established by Hardenbol et al. (1998) for European basins, there is evidence for maximum regression at the scale of Myr transgressiveregressive cycles above Ox6, in the lowermost part of the Bimammatum ammonite zone. In the Swiss Jura Mountains, this interval is recognized at the top of the Röschenz and Günsberg Members (Fig. 2) where plant remains and charophytes imply the presence of soils and fresh water lakes. The overlying Hauptmumienbank and Steinebach Members contain coral framestones, oolites and oncoid-rich wackestones and packstones, thus indicating a transgression that flooded the entire Jura platform. The maximum flooding of the Ox6 sequence is placed at the limit between the Semimammatun and Berrrense subzones (Hardenbol et al., 1998) which would correspond to an interval containing echinoderms, brachiopods and corals in the studied sections (Fig. 5, within small-scale sequence 10). The general evolution of the sedimentary systems recorded in the Swiss Jura thus was at least partly related to changes in sea-level that can be recognized all over Europe.

The high-resolution sequence-stratigraphic and cyclostratigraphic analysis of the Middle and Late Oxfordian strata in the Jura Mountains reveals that facies distribution was strongly heterogeneous through space and time (Pittet, 1996; Dupraz, 1999; Hug, 2003; Védrine, 2007; Stienne, 2010). Controlling factors for this analysis were differential subsidence creating basin morphology, high-frequency sea-level fluctuations modifying water depth and current patterns that distributed the sediment. Facies changes and bounding surfaces define sedimentary sequences (commonly displaying a deepening-shallowing trend) which are hierarchically stacked. Within the time frame given by biostratigraphy and chronostratigraphy (Fig. 3), it has been shown by the authors mentioned above that many of these sequences correspond to the orbital cycles of precession and eccentricity. The definition of the small-scale sequences shown in Fig. 5 is based on the compilation performed by Strasser (2007). It is suggested that the interval between sequence boundary Ox6 and the maximum regression at the top of the Röschenz and Günsberg Members corresponds to four smallscale sequences. As one small-scale sequence corresponds to the short eccentricity cycle of 


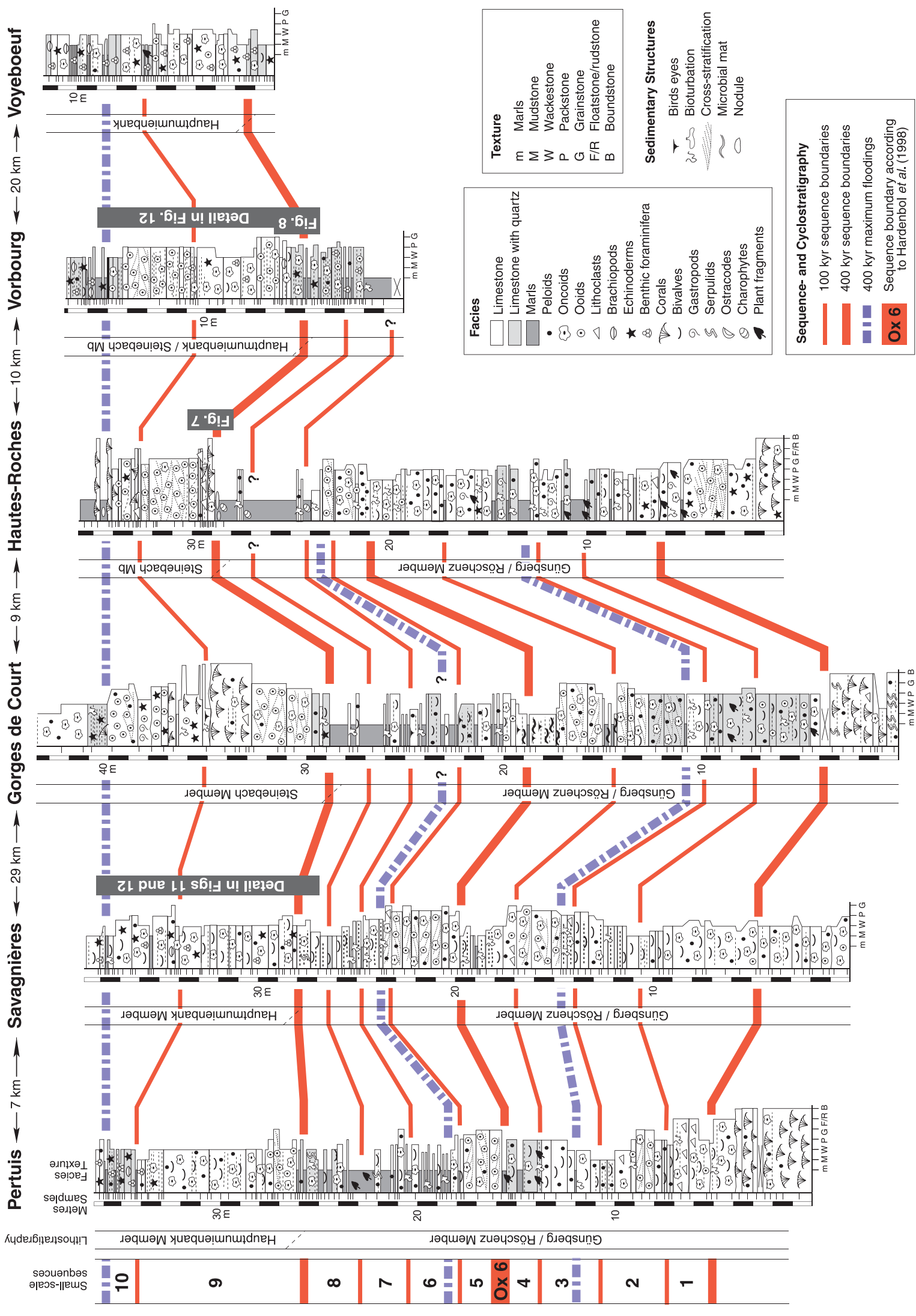

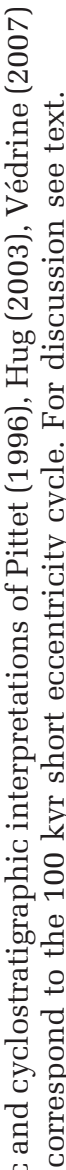


$100 \mathrm{kyr}$, this interval would represent the long eccentricity cycle of $400 \mathrm{kyr}$ (Berger et al., 1989; Strasser et al., 2006). The maximum-flooding surface of this $400 \mathrm{kyr}$ sequence is placed at the top of ooid shoals at Pertuis, Savagnières and Hautes-Roches, above which the facies implies lower energy and more clay input due to progradation of the highstand deposits. The maximum flooding within small-scale sequence 10 (which is also the maximum flooding of a $400 \mathrm{kyr}$ sequence) is the one mentioned in the chart of Hardenbol et al. (1998) at the SemimammatunBerrrense subzone boundary.

The small-scale sequences are composed of individual beds or groups of beds which, in many cases, can again be described as sedimentary sequences (examples of field aspect are shown in Fig. 6). These sequences are termed elementary sequences and are the smallest units within which facies evolution indicates a deepeningshallowing trend, and/or where the bounding surfaces suggest a sea-level drop (Strasser et al., 1999). The interpretation of these sequences, however, often is difficult because autocyclic processes, inherent to the depositional system, also played a role. These processes include progradation or lateral migration of sedimentary bodies, such as tidal flats, shoals or delta lobes, creating shallowing-up facies trends (Ginsburg, 1971; Pratt \& James, 1986; Satterley, 1996). Burgess \& Wright (2003) and Burgess (2006) also showed by forward modelling that changes in carbonate production rate and changes in sediment transport direction through time can create complex and repetitive stratal patterns. These processes are independent of eustasy and/or platform-wide subsidence but depend on local ecological parameters, current patterns, channel migration, lobe switching and/or sea-floor morphology. Consequently, the stacking of beds resulting from autocyclic processes will display a disordered pattern, or an ordered pattern but with limited lateral consistency (Drummond \& Wilkinson, 1993; Burgess, 2006). Nevertheless, if five elementary sequences are seen to compose a well-defined small-scale (100 kyr) sequence and if they exhibit lateral consistency, they can be tentatively attributed to the precession cycle with a duration of $20 \mathrm{kyr}$ (Berger et al., 1989). With this, there is a potential to obtain a time resolution of 20000 years for the study of environmental changes on the Jura platform.

In the following, the focus will be set on the topmost elementary sequence of small-scale sequence 8 , on small-scale sequence 9 and on the transgressive part of small-scale sequence 10 , i.e. on an interval that lasted about $170 \mathrm{kyr}$ (Védrine, 2007). An even higher time resolution has been obtained by Stienne (2010) who concentrated on the interval around the limit between small-scale sequences 8 and 9 (Figs 7 , 8 and 9). This interval has been chosen because it represents the beginning of a long-term transgression. Consequently, a good preservation potential can be expected due to the creation of accommodation on the platform.

\section{SEA-LEVEL CHANGES}

The vertical facies evolutions defining the sedimentary sequences reflect changes in water depth. Accommodation is created by eustatic sea-level rise and by subsidence, and this space is filled depending on the availability of sediment, on the hydrodynamic conditions and on the growth potential of framebuilders (Schlager, 1993; Immenhauser, 2009). Water depth is difficult to estimate in the studied $170 \mathrm{kyr}$ interval. Birdseye structures indicating a tidal flat have been observed only at metre 35 of the Gorges de Court section (Fig. 5). Otherwise, no features (such as root traces or charophytes) implying intertidal to supratidal conditions have been observed. Hermatypic corals thrive in water depths of a few centimetres to a few tens of metres (depending on wave energy and the depth of the photic zone) but coral clasts can be thrown onto the beach or roll down into deeper water. The cross-stratification in the oolites points to the activity of tidal currents, which are most active from the intertidal zone down to several metres water depth (Immenhauser, 2009). Marls and sediments rich in carbonate mud accumulate below wave base, i.e. in deeper environments than the winnowed grainstones, or else in shallow water where barriers protect them from high energy. Stenohaline organisms, such as brachiopods and echinoderms, indicate normal-marine conditions but do not inform about water depth. Based on such vague indications it is not possible to reconstruct a curve of water-depth change and even more difficult to reconstruct a relative sea-level curve. Nevertheless, approximations of such curves have been attempted for elementary sequence 5 in small-scale sequence 8 of the Vorbourg section (Fig. 10).

The detailed analysis of this sequence shows that the sedimentary record is by no means continuous (Stienne, 2010; Fig. 9). Subtle discontinuity 

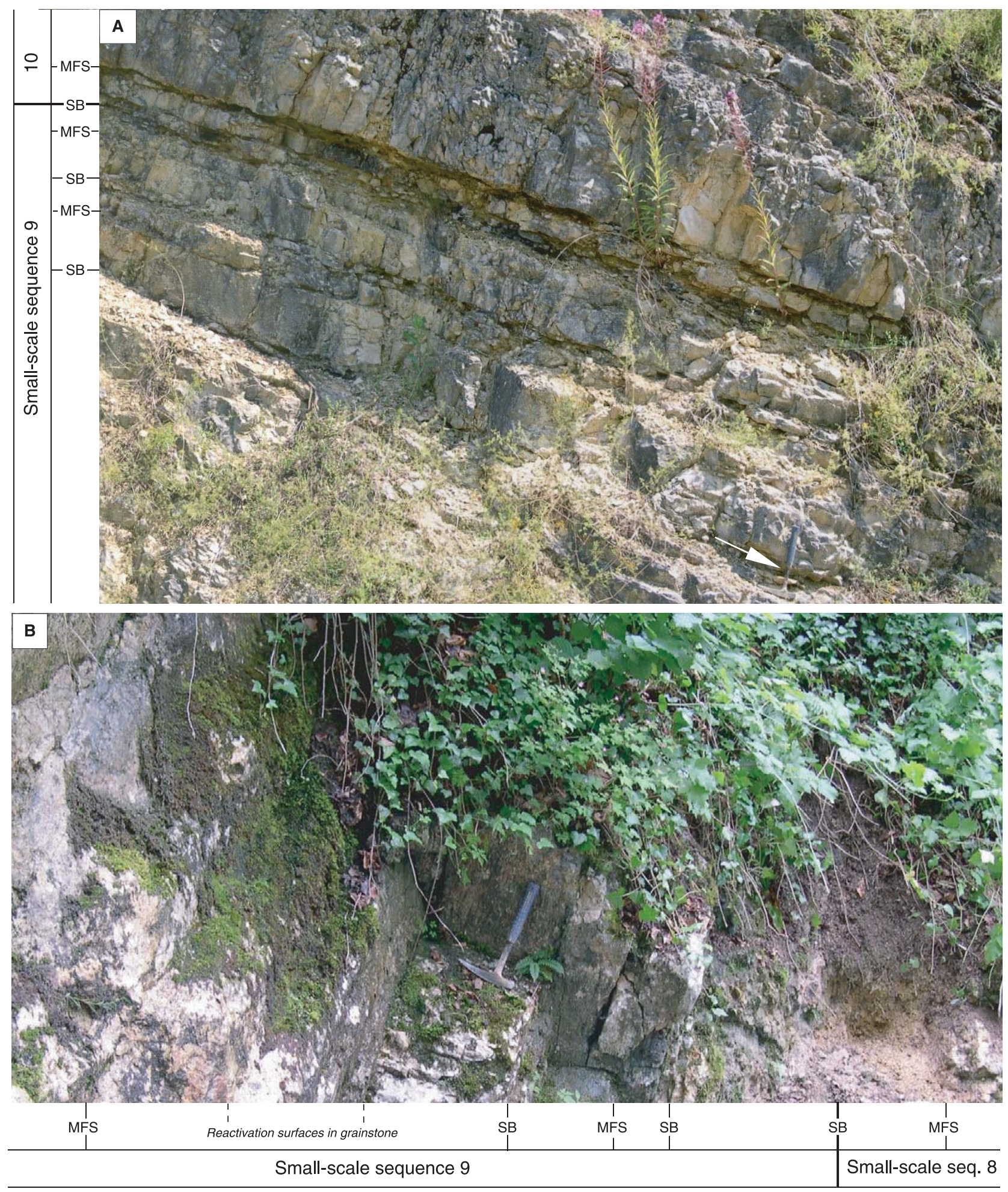

Fig. 6. Outcrop photographs to illustrate the field aspect of the studied intervals. (A) Voyeboeuf section: upper part of small-scale sequence 9 and base of small-scale sequence 10. Sequence boundaries (SB) and maximum-flooding surfaces (MFS) of elementary sequences are indicated. See hammer (white arrow) for scale (33 cm long). (B) Vorbourg section: top of small-scale sequence 8 and lower part of small-scale sequence 9. Sequence boundaries and maximumflooding surfaces of elementary sequences are indicated. The grainstones in the transgressive part of the third elementary sequence of small-scale sequence 9 display autogenic reactivation surfaces (compare with logs in Figs 8 and 12). Hammer for scale. 


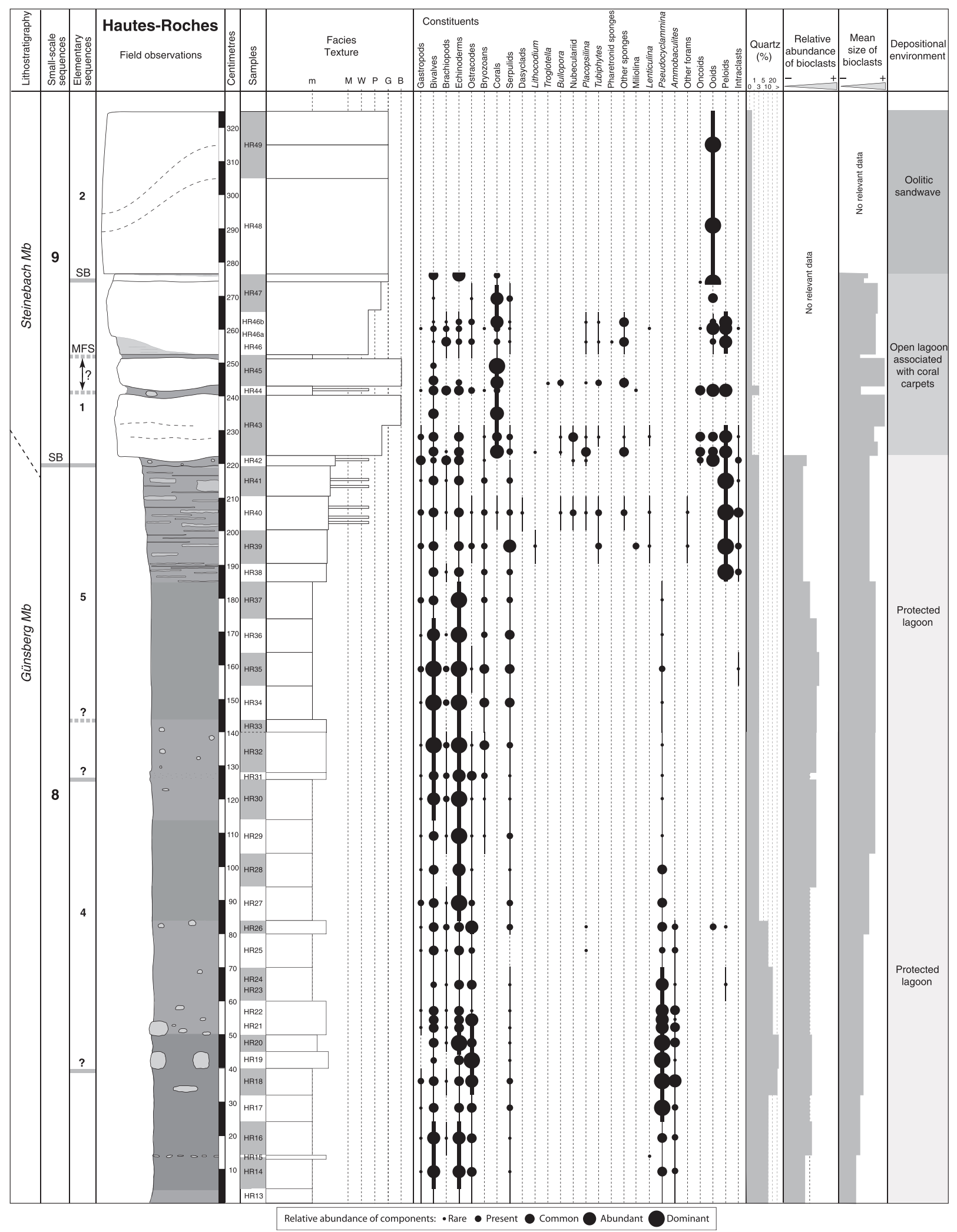

Fig. 7. Detailed log of the top of small-scale sequence 8 and the base of small-scale sequence 9 at Hautes-Roches (compare with Fig. 5). Elementary sequences are numbered 1 to 5 within a small-scale sequence. The samples cover $100 \%$ of the outcrop. The environmental interpretation is based on the relative abundances of the constituents (estimated in thin section) and on sedimentary structures. Symbols are explained in Fig. 5. SB, sequence boundary; MFS, maximum-flooding surface. Modified from Stienne (2010). 


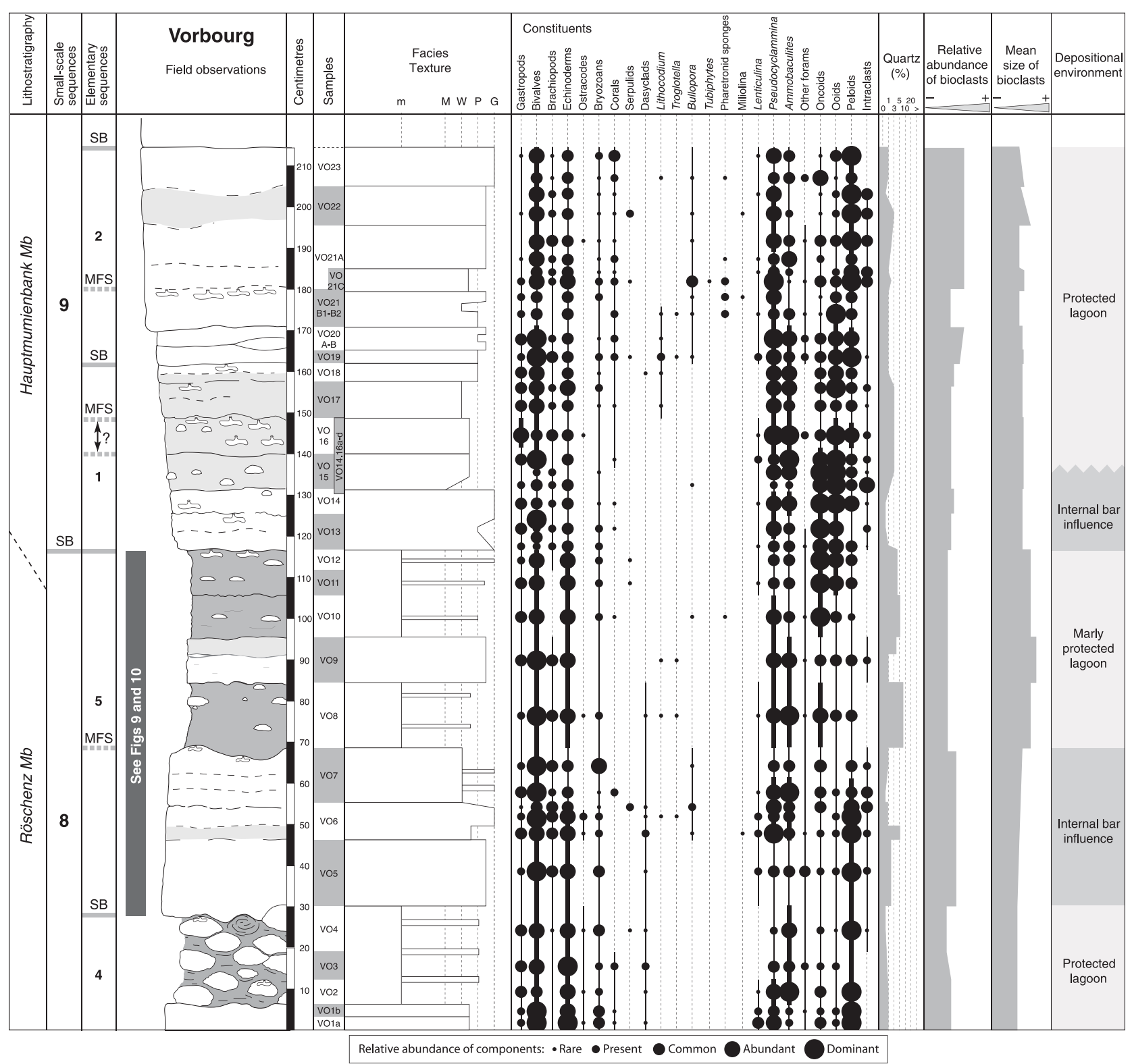

Fig. 8. Detailed log of part of the Vorbourg section. For more explanation see legend to Fig. 7, for symbols see Fig. 5. Modified from Stienne (2010).

surfaces are indicated by thin mudstone deposits that suggest low-energy conditions, by accumulations of shells in convex-up position implying increased current activity, or by a concentration of bioturbation suggesting lower sedimentation rates. Umbrella structures (shelter porosity) indicate that carbonate mud has settled after the deposition of a shell in convex-up position. The orientation of the fossil components commonly is horizontal (possibly enhanced by compaction) but locally also oblique or vertical; this is explained by the activity of burrowing animals that displaced the components. Fossils containing geopetal cavity fills (gastropods, corals or ostracodes) are often seen to have been rotated. Sample VO9 is interpreted as an amalgamation of at least two storm deposits that are separated by a thin mudstone layer. Dolomitization and dedolomitization imply that fluids have circulated through the sediment, locally aided by porosity and permeability contrasts between burrows and encasing sediment. The limestone nodules in samples VO8 to VO12, formed by early diagenetic accretion of carbonate around carbonate grains within the sediment (Savrda \& Bottjer, 1988), probably enhanced by the dissolution of aragonite in the sulphate reduction zone (Cherns et al., 2008). Incipient hardgrounds can form rapidly 

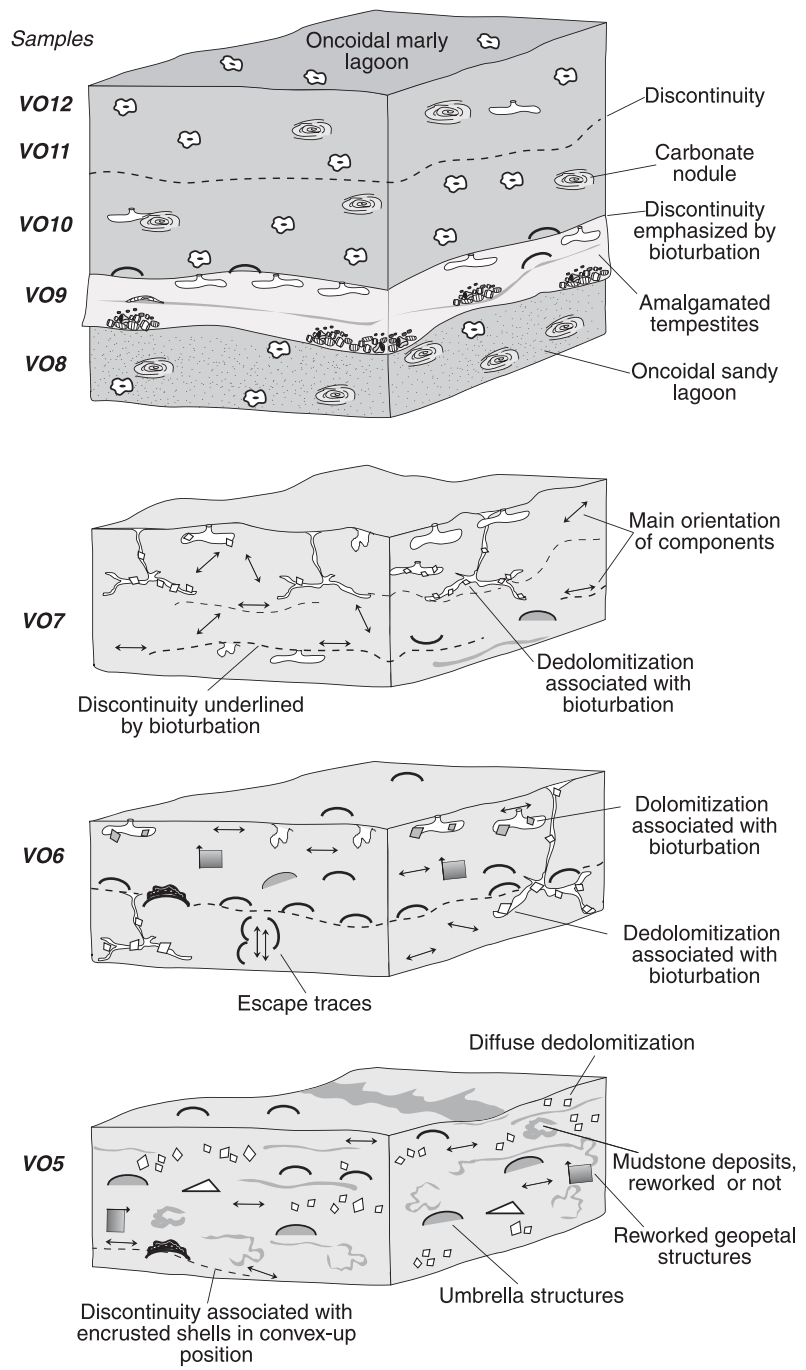

Fig. 9. Three-dimensional sketches of selected samples of the Vorbourg section, showing sedimentological and diagenetic features as well as discontinuity surfaces (not to scale). Compare with Fig. 8; for symbols see Fig. 5. Modified from Stienne (2010).

(within a few months or years) on the sea floor when sediment accumulation is interrupted, first by microbial binding, then by cementation (Dravis, 1979; Hillgärtner et al., 2001). Fragmentation, wearing, micritization, perforation and encrustation of the fossil remains show moderate to high taphonomic grades (as defined by Flessa et al., 1993), suggesting that they have resided in the taphonomically active zone (Davies et al., 1989) for a relatively long time.

In order to reconstruct a hypothetical sea-level curve, the sediment first has to be decompacted in order to estimate the minimum space available at the time of sediment accumulation. Mechanical reorganisation of grains and dewatering in carbonate mud leads to a porosity loss of 10 to $30 \%$ after the first $100 \mathrm{~m}$ of burial (Moore, 1989). The experiments of Shinn \& Robbin (1983) gave 20 to $70 \%$ of volume loss through mostly mechanical and dewatering compaction. These values will be less if carbonate cementation sets in very early (Halley \& Harris, 1979). With deeper burial, chemical compaction becomes important. Burial of over $2 \mathrm{~km}$ probably never occurred in the Jura Mountains (Trümpy, 1980) but pressure solution at grain contacts testifies to some dissolution in the studied sediments. Goldhammer (1997) proposes a compaction of slightly over $50 \%$ for carbonate mud buried at $1000 \mathrm{~m}$, and of about $15 \%$ for carbonate sand at the same burial depth. According to Enos (1991), muddy terrigenous and muddy carbonate sediments do not have significantly different compaction curves. However, pressure solution along clay seems enhances chemical compaction in carbonates (Bathurst, 1987). Based on these published values, the following decompaction factors are applied: $1 \cdot 2$ for grainstones and 2.5 for mudstones. For packstones and wackestones, the intermediate factors 1.5 and 2 are assumed, for marls the factor is 3 (Strasser \& Samankassou, 2003).

In the Late Jurassic, continental ice in high latitudes and on mountains was probably present but volumes were small (Fairbridge, 1976; Frakes et al., 1992; Eyles, 1993; Price, 1999). Orbitally controlled climate changes thus would have resulted in only minor glacio-eustatic sea-level fluctuations. However, insolation changes certainly contributed to low-amplitude sea-level fluctuations through thermal expansion and retraction of the uppermost layer of ocean water (Gornitz et al., 1982). The sea-level rise of today is due half to melting of continental ice and half to thermal expansion (IPCC, 2007). In addition, thermally induced volume changes in deep-water circulation (Schulz \& Schäfer-Neth, 1998), and/or water retention and release in lakes and aquifers (Jacobs \& Sahagian, 1993) could have contributed. Because slow build-up and rapid melting of polar ice caps, such as in the Quaternary, was not the dominant process, it is assumed that orbitally controlled insolation changes translated more or less directly into eustatic sea-level changes that thus were symmetrical (Read, 1995). Based on the decompacted thicknesses of elementary and small-scale sequences (corresponding to the precession and short eccentricity cycles, respectively), amplitudes are estimated at a few metres only for Late Jurassic and Early Cretaceous times (Strasser \& Samankassou, 2003; Strasser et al., 2004). For comparison, Crevello (1991) proposed 


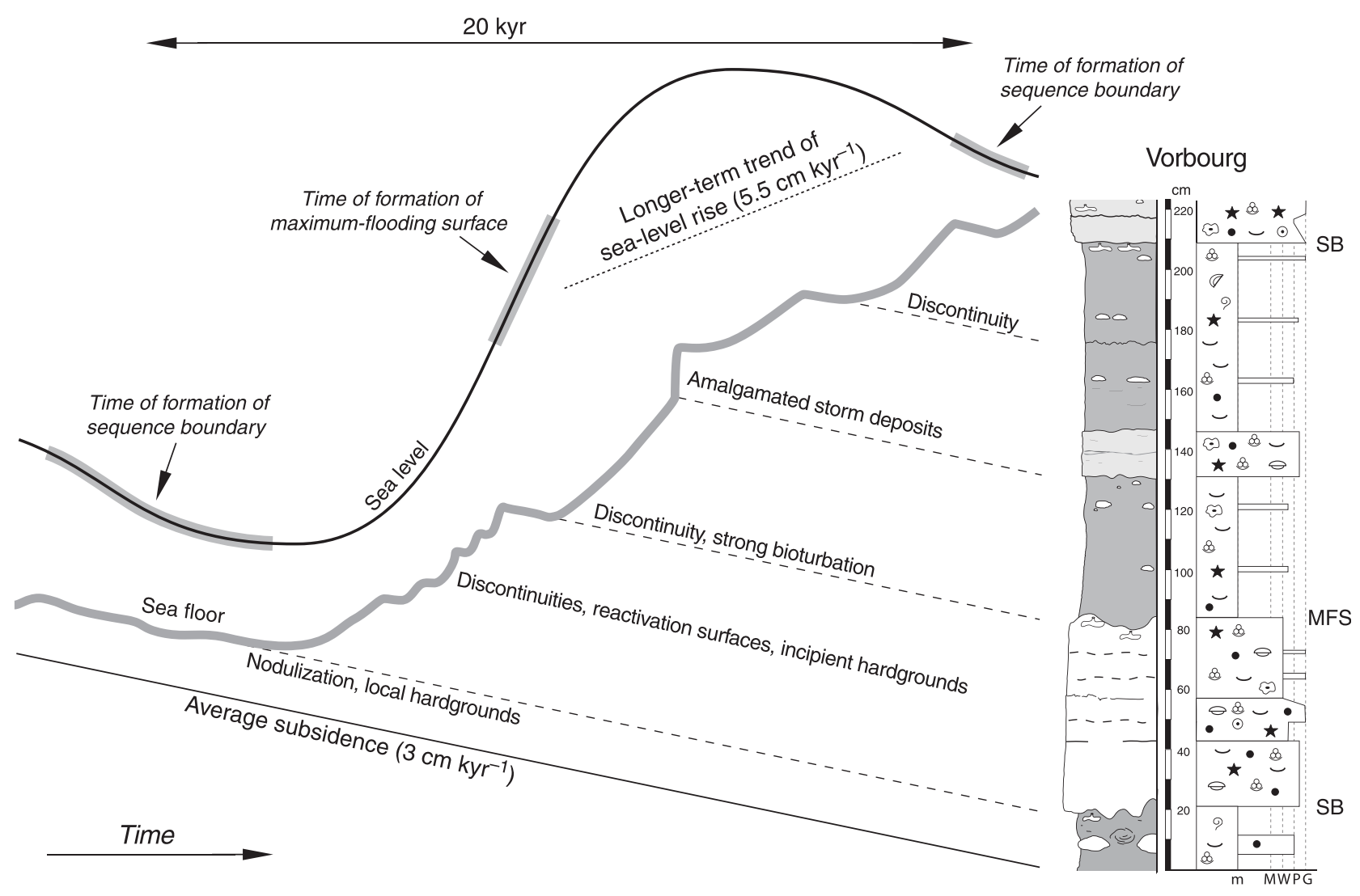

Fig. 10. Tentative reconstruction of the evolution of the sea floor and eustatic sea-level throughout a 20 kyr time interval, based on the differentially decompacted elementary sequence 5 at Vorbourg (see Fig. 8). For discussion refer to text, for symbols see Fig. 5.

2 to $3 \mathrm{~m}$ amplitudes for precession-controlled high-frequency sea-level fluctuations recorded on an Early Jurassic carbonate platform in Morocco, and Aurell \& Bádenas (2004) estimated 5 to $10 \mathrm{~m}$ for amplitudes of sea-level changes probably induced by eccentricity cycles on a Late Kimmeridgian carbonate ramp in Spain.

In the reconstruction of Fig. 10, the differentially decompacted elementary sequence is shown. The duration is assumed to have been $20 \mathrm{kyr}$, corresponding to a precession cycle. The sea-level cycle is assumed to be symmetrical but superposed on a longer-term rising trend to allow deposition of the sequence without subaerial erosion. The amplitude is drawn arbitrarily at $110 \mathrm{~cm}$ but is in the range of amplitudes of highfrequency eustatic sea-level changes reconstructed for Berriasian sediments of the Jura platform where intertidal features permit better estimations (Strasser et al., 2004). The evolution of the sea floor through time is interpreted from the sedimentary record. Some subtidal erosion and non-deposition at the base of the sequence allowed for nodulization in the sediment below. During the corresponding time interval, a sequence boundary formed. The overlying limestone beds are interpreted as corresponding to transgressive deposits when rising relative sealevel kept the siliciclastics in a more landward position. The sediment accumulation was repeatedly interrupted by phases of reactivation by currents and non-deposition, creating discontinuities and incipient hardgrounds. The undulating surface rich in bioturbation is seen as the turn-around between retrogradation and progradation, i.e. as the maximum-flooding surface. Slowing down of relative sea-level rise permitted progradation of the siliciclastics, which dominate in the highstand deposits; these are interrupted by amalgamated storm deposits that accumulated almost instantly. A discontinuity surface points to a lower sediment accumulation rate, allowing for consolidation of the marly sediment. The carbonate nodules preserved the original texture of sediment probably washed in by storms. The second sequence boundary is placed at the base of the following limestone bed.

The sea-level curve is tied to the two sequence boundaries (fastest drop) and to the maximumflooding surface (fastest rise). The water depth is 
chosen at a minimum (a few tens of centimetres) but could have been a few metres. The general trend, however, implies a longer-term rise of some $5.5 \mathrm{~cm} \mathrm{kyr}^{-1}$, if subsidence is taken at $3 \mathrm{~cm} \mathrm{kyr}^{-1}$, which corresponds to the average rate for the Late Jurassic of the Swiss Jura as indicated by Wildi et al. (1989). For comparison, Ramajo \& Aurell (2008) estimated that long-term sea-level rise during the Bimammatum zone was about $2 \mathrm{~cm} \mathrm{kyr}^{-1}$, based on their study of a Callovian-Oxfordian section in Spain. The higher value obtained for the interval analyzed in Fig. 10 seems realistic because it formed during the transgressive phase following sequence boundary Ox6 (Fig. 2; Strasser, 2007). According to the graphical representation in Fig. 10, the fastest sea-level rise occurred 8600 years after the beginning of the $20 \mathrm{kyr}$ cycle with a rate of $30 \mathrm{~cm} \mathrm{kyr}^{-1}$ (for comparison, global average sea-level rise was around $310 \mathrm{~cm} \mathrm{kyr}^{-1}$ for the period 1993 to 2003; IPCC, 2007).

\section{TERRIGENOUS INPUT}

In the studied sections, siliciclastics occur in laterally and vertically varying proportions (Fig. 5); their source areas are the emerged lands surrounding the Jura platform (Fig. 1; Gygi \& Persoz, 1986). The quartz grains are sub-angular, their diameters range from 0.02 to $0.1 \mathrm{~mm}$; they can locally constitute up to $40 \%$ of the sediment but, in general, are below $10 \%$. Feldspars and heavy minerals are associated in low quantities. High quartz content preferentially occurs around the small-scale and elementary sequence boundaries (Fig. 11; Védrine, 2007).

Clay-mineral analyses have been performed on 22 samples of the Savagnières section (Fig. 11). Illite and chlorite trends are similar and are both inverse to the kaolinite trend. The mixed-layer illite-smectite trend preferentially correlates with the kaolinite trend. The scarcity of smectites and the relative abundance of mixed-layer clays are typical of the Oxfordian of the Swiss Jura (Gygi \& Persoz, 1986). Either the scarcity of smectite is an original feature, or it is due to the transformation of smectites into mixed-layer illite-smectite and illite by burial diagenesis or by transformation in soils (Gygi \& Persoz, 1986; Chamley, 1989). Chlorite content generally is higher around the small-scale and elementary sequence boundaries and lower around the maximum floodings. Mixed-layer illite-smectite content is higher around the small-scale sequence boundaries and occasionally around the elementary ones. In addition, a high content of mixed-layer illitesmectite also occurs around the small-scale maximum floodings, while the lowest values exist around the elementary maximum floodings. The kaolinite trend presents low values at the base of the section and then increases significantly but a link with the sequence-stratigraphic interpretation cannot be detected. Illite is abundant around some sequence boundaries but not around others; a systematic relationship is not discernible. The kaolinite-illite ratio displays higher values around the small-scale sequence boundaries, as well as around the small-scale maximum floodings. The generally low illite crystallinity index points to detrital illites, in agreement with the low burial depth of the Swiss Jura (Trümpy, 1980). The relatively highest values (corresponding to poorly crystallized illites) occur around small-scale and elementary sequence boundaries.

The erosion of siliciclastics from the crystalline massifs in the hinterland and their transport onto the platform was controlled by sea-level and rainfall over the emerged lands. Low sea-level increases the erosion potential by river incision and favours the progradation of coastal deltas. Increased land surface also increases the potential for clay formation in soils (depending on the type of substrate and the climate conditions; Retallack, 2001). During transgression, these clays are then remobilized and distributed over the platform. Increased rainfall favours alteration of the bedrock and enhances the erosion potential. The rivers are more active and transport the siliciclastics towards the platform. Aeolian transport cannot be excluded but it is assumed that most of the siliciclastics encountered on the Jura platform were furnished by rivers (Gygi \& Persoz, 1986).

Carbonate islands formed locally and episodically on the platform itself, as implied by charophytes at Hautes-Roches and plant fragments at Pertuis, Gorges de Court, Hautes-Roches and Voyeboeuf (Fig. 5). However, their surface areas were probably not large enough and their life spans not long enough to sustain significant soil formation.

The kaolinite-illite (K/I) ratio is commonly used for palaeoclimate reconstruction and reflects the influence of climate and relief changes on chemical weathering and soil formation. A high $\mathrm{K} / \mathrm{I}$ ratio generally indicates a more humid, warm climate (Curtis, 1990; Thiry, 2000). Deconinck (1993) found that kaolinite preferentially accumulates in proximal platform areas. In the 
Savagnières section, the higher K/I ratios around the sequence boundaries would thus suggest a more humid climate at falling sea-level, concomitant with increased erosion as indicated by the higher quartz contents. However, the K/I ration is also high around the maximum flooding of smallscale sequences 9 and 10, albeit without being associated with marls or a higher quartz content (Fig. 11). This effect can be explained by a humid climate at those times but less erosion due to rapidly rising sea-level, or by remobilization of kaolinite during the extensive flooding of the platform.

In the Oxfordian of the Swiss Jura, siliciclastics (clays and quartz) are concentrated mainly around the sequence boundaries, i.e. they were furnished during falling sea-level. Small-scale (100 kyr) sequences have been compared between the Swiss Jura and time-equivalent outcrops in the Soria region in Spain (Pittet \& Strasser, 1998). There, siliciclastics are concentrated around the maximum-flooding intervals. This contrast is explained by a humid climate at falling sea-level in the Jura, while in Spain it was arid, and by a more arid climate at rising sea-level in the Jura while it was raining in Spain. It thus seems that the palaeolatitudinal difference between the Jura (26 to $27^{\circ} \mathrm{N}$ ) and Spain (23 to $24^{\circ} \mathrm{N}$; Dercourt et al., 1993) was sufficient to create these opposing climate trends. The shifting of atmospheric circulation cells in tune with the orbital cycles is seen as the driver of these climate changes (Matthews \& Perlmutter, 1994).

Together with siliciclastics, also nutrients were washed into the platform waters; this is demonstrated by the coral patch reefs where encrustations by microbialites are common. The succession from clean coral surfaces to microencrusters (for example, foraminifera, red algae, serpulids, bryozoans and sponges) and then to microbialites implies an evolution from oligotrophic to mesotrophic and, finally, to eutrophic conditions (Dupraz, 1999; Dupraz \& Strasser, 2002).

The distances from the eroded massifs to the study area are several hundreds of kilometres (Fig. 1). Consequently, it is likely that the siliciclastics were first deposited close to the source areas at the delta mouths and then transported by currents onto the Jura platform. An additional factor is the channelling of the siliciclastics through morphological depressions on the platform as shown by Pittet (1996) and Hug (2003) which results in a heterogeneous lateral distribution. Quartz and clays may have been ponded in such depressions for a while before they were remobilized by high-energy events and transported to other areas. These processes may have occurred with significant time lags, explaining why the correlation between abundance of siliciclastics and sea-level changes is not straightforward. Furthermore, sediment mixing through storm reworking and bioturbation may have caused time-averaging over a depth of several tens of centimetres, corresponding to a few hundred to a few thousand years depending on sedimentation rate (Flessa et al., 1993; Kidwell et al., 2005).

\section{CARBON AND OXYGEN ISOTOPES}

Carbon $\left({ }^{13 / 12} \mathrm{C}\right)$ and oxygen $\left({ }^{18 / 16} \mathrm{O}\right)$ isotope ratios have been measured on 20 samples in the Vorbourg section and on 24 samples in the Savagnières section (Fig. 12; Védrine, 2007). The $\delta^{13} \mathrm{C}$ values vary between -0.5 and $+2 \%$ in both sections, while the $\delta^{18} \mathrm{O}$ values vary between -4 and $-5 \%$ at Savagnières and between -3.5 and $-5 \cdot 5 \%$ at Vorbourg. There is no correlation between $\delta^{18} \mathrm{O}$ and $\delta^{13} \mathrm{C}$, suggesting that the original isotopic signal was not significantly altered by diagenesis (Allan \& Matthews, 1982). There is no discernible, systematic relationship to sequence boundaries or maximum-flooding surfaces, and there are no correlatable trends between the two sections.

In Berriasian peritidal carbonates of the Swiss and French Jura, Joachimski (1994) has shown that $\delta^{13} \mathrm{C}$ values are commonly depleted below emersion surfaces, implying the influence of soilderived $\mathrm{CO}_{2}$. In parallel, $\delta^{18} \mathrm{O}$ may be enriched because of removal of ${ }^{16} \mathrm{O}$ in the pore waters through evaporation. The sequences analysed here do not show any sedimentological signs of prolonged emersion, which is confirmed by the absence of diagnostic shifts in the isotope record.

Oxidation of organic matter, photosynthesis and respiration can cause water masses on carbonate platforms to develop $\delta^{13} \mathrm{C}$ values significantly different from those of the open ocean (Patterson \& Walter, 1994; Immenhauser et al., 2003; Colombié et al., 2010). The $\delta^{18} \mathrm{O}$ values depend on temperature and salinity, which can both vary considerably through space and time in shallow platform waters. Plunkett (1997) calculated palaeotemperatures of 26 to $27^{\circ} \mathrm{C}$ from Middle Oxfordian samples on the Swiss Jura platform, based on an average $\delta^{18} \mathrm{O}$ value of $-3.5 \%$. Frakes et al. (1992) indicate up to $27^{\circ} \mathrm{C}$ 


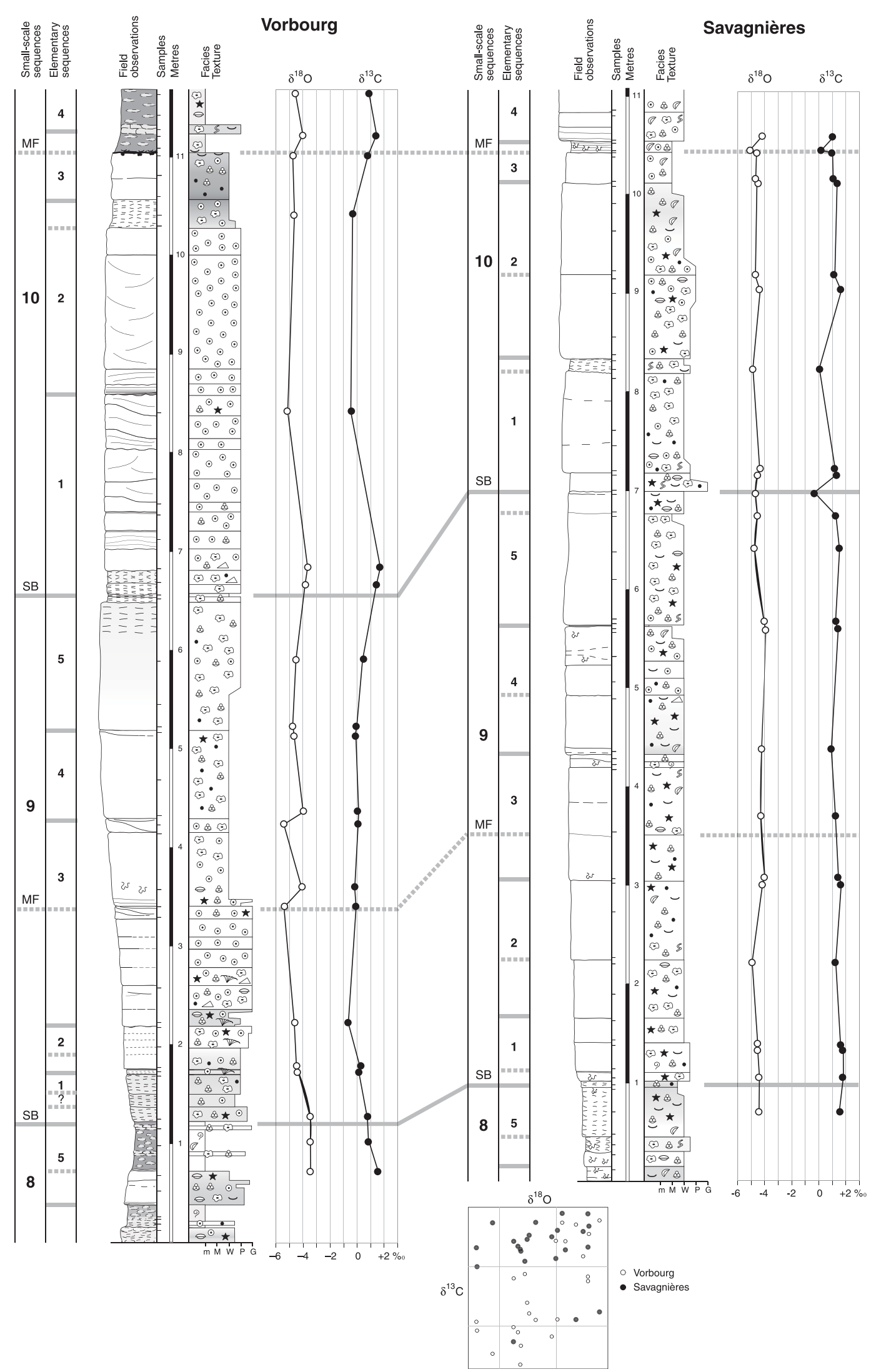

Fig. 12. Distribution of $\delta^{13} \mathrm{C}$ and $\delta^{18} \mathrm{O}$ values in the Vorbourg and Savagnières sections. Modified from Védrine (2007). For discussion refer to text. SB, sequence boundary; MF, maximum flooding. For symbols see Fig. 5. 
for the Late Oxfordian ocean surface temperatures, according to oxygen isotopes measured on planktonic foraminifera and belemnites.

Whereas the facies trends in the sedimentary sequences suggest sea-level changes and the claymineral assemblages imply changes of the climate in the hinterland, the $\mathrm{C}$ and $\mathrm{O}$ isotope values of the two studied sections do not exhibit fluctuations that would indicate significant environmental changes. The slight variations through time and between the sections may be attributed to differences in the original composition of the carbonate, to differences in the water masses that furnished $\mathrm{C}$ and $\mathrm{O}$ to the carbonate-producing organisms, and to differences in the composition of the pore fluids that induced the early diagenetic stabilization of the carbonate (Van der Kooij et al., 2009). Such differences are to be expected on a structured carbonate platform where lateral and vertical facies changes were common (facies mosaics; Strasser \& Védrine, 2009), where sealevel and climate changes influenced temperature and salinity of the ocean water, and where early diagenesis was compartmentalized due to local and episodic emersion and installation of fresh water lenses (as evidenced through cathodoluminescence studies of cements by Plunkett, 1997). In addition, time-averaging through bioturbation and storm reworking probably homogenized the original signals.

\section{BIOTIC CHANGES}

The rapid change from marl-dominated to limestone-dominated lithologies at the boundary between the Günsberg/Röschenz and Hauptmumienbank/Steinebach Members (Figs 2 and 5) is related to a major transgression during which the input of siliciclastics on the Jura platform was reduced, accommodation increased, and coral reefs and ooid shoals were installed. However, the marine influence was felt well before, as indicated by the relatively abundant echinoderms (crinoids and echinoids) and brachiopods found in the upper part of the Günsberg/Röschenz Members (Figs 7 and 8). These organisms thrived in marly, protected lagoons in association with gastropods, bivalves, ostracodes, bryozoans and serpulids. Benthonic foraminifera, especially Pseudocyclammina and Ammobaculites, are common to abundant in the Vorbourg section, in the marly as well as in the limestone-dominated intervals. At Hautes-Roches, these two genera concentrate in an interval towards the base of the studied section (Fig. 7). Dasycladacean algae and corals in these marly members are found in low abundances and mainly within limestone beds and nodules (Fig. 8).

Corals occur in low abundance in the oncoidrich Hauptmumienbank Member but dominate the coral levels of the Steinebach Member at Gorges de Court and Hautes-Roches. In the latter outcrop, these levels are interpreted as coral carpets, the growth of which was periodically interrupted (see below). Coral diversity is low and dominated by Isastraea and Microsolenida (Dupraz, 1999). Bioerosion producing Gastrochaenolites was important. The dominant microencrusters are Placopsilina, Bullopora and Nubecularids, and also columnar microbialite is found (Dupraz, 1999; Stienne, 2010). The rapid change from marl-dominated sediment to coral carpet can be explained at least partly by a change from mesotrophic to oligotrophic conditions: nutrients associated with the siliciclastics became less abundant and a low-diversity coral growth became possible (Dupraz \& Strasser, 2002).

The oncoids that define the Hauptmumienbank Member (the term 'Mumie' means mummy in German, thus describing the irregular envelopes around a nucleus) already appear in the marly Röschenz Member (Fig. 8). The oncoids encountered in the studied interval at Hautes-Roches, Vorbourg and Voyeboeuf belong to type 2 of Védrine et al. (2007): they are a few millimetres up to $1 \mathrm{~cm}$ in diameter, have smooth surfaces, and may include encrusting organisms such as serpulid worms or Bullopora in their micritedominated cortex. In the Savagnières and Pertuis sections, types 3 and 4 also occur. Type 3 oncoids are up to $5 \mathrm{~cm}$ in diameter, type 4 oncoids measure up to $10 \mathrm{~cm}$. Both types have lobate surfaces and contain Bacinella and Lithocodium (Védrine et al., 2007; but see also the new definition of these organisms as green algae by Schlagintweit et al., 2010). Type 3 has irregularly laminated cortices, type 4 displays no lamination. Type 3 and type 4 oncoids commonly occur together with the foraminifer Mohlerina basiliensis, which suggests similar ecological requirements (Védrine et al., 2007; Védrine, 2008). Type 1 oncoids are found at Gorges de Court: they are a few millimetres across, have smooth surfaces and do not contain microencrusters. While the lobes of type 3 and type 4 oncoids indicate rather lowenergy conditions, the smooth surfaces of types 1 and 2 imply rolling on the sea floor. Types 1 and 2 could form in turbid waters, while types 3 and 4 , with the presence of light-dependent Lithocodium 
and Bacinella, rather suggest clear-water conditions. Growth of Lithocodium and Bacinella crusts has been attributed to elevated nutrient levels (Immenhauser et al., 2005; Schlagintweit et al., 2010). In the Oxfordian of the Swiss Jura, however, these organisms are commonly associated with high coral diversity, thus implying rather oligotrophic conditions (Dupraz, 1999; Dupraz \& Strasser, 2002).

The observed evolution of the fauna and the oncoids (Figs 7 and 8) does not directly reflect sea-level changes but rather changes in trophic conditions. The heterotrophic fauna in the Günsberg/Röschenz Members includes gastropods, notably Bourguetia striata, that grazed on algae and microbial mats, as well as filter feeders such as brachiopods and crinoids (Dupraz, 1999). Siliciclastic input and associated nutrients generally declined during the formation of the Hauptmumienbank and Steinebach Members, but the irregular platform morphology resulted in important lateral differences in environmental conditions. At Hautes-Roches, coral carpets could install themselves on a topographic high, although their growth was interrupted several times by storm events producing rubble, by phases of bioerosion and microbial encrustation, and finally by the advancement of an ooid sandwave (Fig. 7). At the same time, oncoid lagoons formed in depressions. Salinity probably was constant throughout the studied time interval, as no change in the stenohaline fauna is seen.
Bioturbation (mainly Thalassinoides) is visible in most studied samples and implies that the sediment was reworked after deposition, resulting in time averaging over a few tens of centimetres (Stienne, 2010). Also, storm events contributed to erosion and redeposition of bioclasts. The observed distribution of fossils thus does not reflect the exact position of the living organisms and may contribute to the impression that the biotic succession in the lagoons was rather gradual.

\section{HIGH-RESOLUTION CORRELATION}

On the studied Jura platform, the best tool for obtaining a high-resolution correlation between sections is cyclostratigraphy (Fig. 5). Based on the given biostratigraphic and chronostratigraphic framework (Figs 2 and 3), it is assumed that the observed elementary sequences correspond to the $20 \mathrm{kyr}$ orbital precession cycle. In Fig. 13, a correlation of an elementary sequence is attempted between the Vorbourg and HautesRoches sections, in order to evaluate the synchronicity of environmental changes. The sections lie on different anticlines of the folded Swiss Jura, implying that the palaeogeographic distance between them was greater than today's $10 \mathrm{~km}$. While the sequence in Vorbourg is dominated by ooids and oncoids in grainstones, packstones and wackestones, there is a predominance of corals at

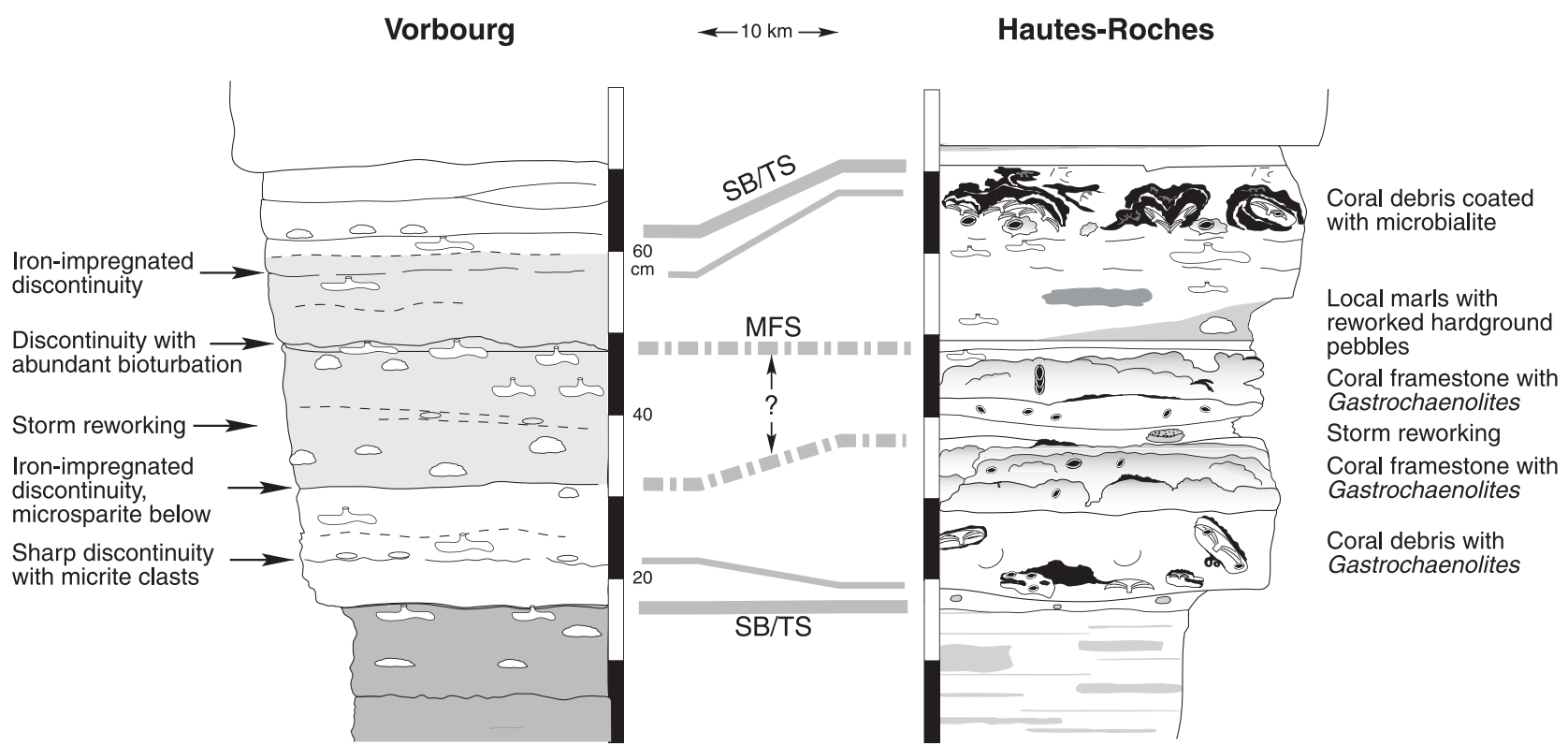

Fig. 13. Tentative correlation of discontinuity surfaces in elementary sequence 1 (at the base of small-scale sequence 9) between Vorbourg and Hautes-Roches (compare with Figs 7 and 8). For discussion see text. SB, sequence boundary; TS, transgressive surface; MFS, maximum-flooding surface. 
Hautes-Roches (Figs 7 and 8). The sequence boundary, directly overlain by the transgressive surface, is placed at the base of the limestone bed at Vorbourg and at the base of the still marly but already ooid-containing thin bed below the coral debris at Hautes-Roches.

The first discontinuity at Vorbourg is marked by micrite clasts, suggesting reworking of cohesive carbonate mud by currents or waves. Since the encasing sediment is a grainstone (Fig. 8), a quiet phase for the deposition of this carbonate mud must be postulated. At Hautes-Roches, the lower part of the sequence contains coral debris, implying growth of a coral carpet in quiet water and its subsequent destruction. Consequently, it is possible that the coral rubble at HautesRoches and the micrite clasts at Vorbourg formed at the same time through the same high-energy phase. The second discontinuity at Vorbourg is iron-impregnated, implying a reduced sedimentation rate. Enhanced circulation of pore fluids also led to microsparitization. At Hautes-Roches, the coral carpet that had grown on the rubble shows signs of demise (bioerosion and microbial crusts), probably due to a change in environmental conditions from oligotrophic to mesotrophic or eutrophic. The same environmental change would have induced reduced sedimentation at Vorbourg. Reworked coral and bivalve fragments at Hautes-Roches and shell accumulations at Vorbourg then imply storm activity.

The third discontinuity at Vorbourg is underlined by abundant bioturbation, implying a reduced sedimentation rate that allowed a concentration of burrows. This surface is correlated with the surface on top of the second coral framestone interval at Hautes-Roches, where a hardground developed that is now found as reworked pebbles in the overlying marls. Both the second and the third discontinuity show characteristics of maximum-flooding surfaces whereby an increased rate of sea-level rise led to sediment starvation and clay and nutrient input to a demise of the corals. Sedimentation then picked up again, but the iron-impregnation of the fourth discontinuity at Vorbourg implies a renewed change in environmental conditions. This possibly was contemporaneous with the important eutrophication at Hautes-Roches as indicated by the thick microbialite crusts on the coral fragments. The sequence boundary and transgressive surface of the following elementary sequence is placed at the base of the bed containing reworked bivalves and iron-impregnated clasts at Vorbourg, and at the base of the thin ooid bed below the sandwave at Hautes-Roches.

The correlation of these discontinuities of course is speculative, because sediment starvation can be caused by local factors and its timing can vary from one location to another. Eutrophication can affect a large water mass but its impact on the biota may be modified by local conditions. Consequently, nothing can be said about the time needed for the formation of these surfaces or about their synchronicity, if not that they occur within the same elementary sequence, i.e. that they formed during the same $20 \mathrm{kyr}$ precession cycle. If sequence-stratigraphic elements (such as a maximum-flooding surface) can be identified within an elementary sequence, the time resolution can be somewhat improved by differentiating an earlier and a later part of the $20 \mathrm{kyr}$ interval.

\section{DISCUSSION: ESTIMATION OF SPEED AND SYNCHRONICITY}

In order to evaluate the rates and synchronicity of environmental changes in the geological past, a precise time framework is needed. In the Late Jurassic, the best available biostratigraphic time resolution by ammonite subzones is in the order of a few $100 \mathrm{kyr}$ (Hardenbol et al., 1998). This time resolution depends, however, on the quality of the radiometric dates against which the biostratigraphy is calibrated. For example, Schoene et al. (2010) were able to constrain the duration of the extinction interval at the Triassic-Jurassic boundary to less than $290 \mathrm{kyr}$. Cyclostratigraphy can offer a time resolution of $20 \mathrm{kyr}$ (corresponding to the duration of the precession cycle; Strasser et al., 2006). Shifts in $\delta^{13} \mathrm{C}$ may occur within a few thousand years but, because the residence time of carbon in the oceans is on the order of 100 kyr (Weissert et al., 2008), the correlation potential of such shifts is somewhat reduced. Switches in the polarity of the Earth's magnetic field happen within a few thousand years (Langreis et al., 2010). In all cases, a high time resolution is guaranteed only if the studied sediments allow the application of these dating tools, i.e. if the biotic, sedimentary, geochemical or magnetic changes have been faithfully and continuously recorded.

In deep-water sediments, below the influence of tidal currents and waves and in the absence of erosion by bottom currents, it can be assumed that the sedimentary record is complete, and average 
sedimentation rates can be calculated between two dated tie points. Dysoxic or anoxic bottom waters will furthermore reduce time averaging through bioturbation. For example, for the major perturbation in C-cycling leading to the oceanic anoxic event (OAE) 1a, Van Breugel et al. (2007) estimated that the negative shift in $\delta^{13} \mathrm{C}$ just below the black shales of OAE 1a occurred over a time interval of 6 to $14 \mathrm{kyr}$ in the Cismon outcrop in Italy, and over $19 \mathrm{kyr}$ at DSDP Site 463 in the mid-Pacific (assuming constant sedimentation rates and a continuous section). This event has been attributed to release of $\mathrm{CO}_{2}$ at the onset of the Ontong Java large igneous province (Menegatti et al., 1998), or to methane release resulting from gas hydrate dissociation (Beerling et al., 2002). Méhay et al. (2009) analysed the base of the OAE 1a interval in Cismon in detail and concluded that it was rapid (6 to $7 \mathrm{kyr}$ ) $\mathrm{CO}_{2}$ release that induced the negative $\mathrm{C}$-isotope shift and acidification of the ocean, which resulted in reduced calcification of calcareous nannofossils (Weissert \& Erba, 2004).

Another example of a deep-sea record of environmental change is sapropel S1 in the eastern Mediterranean. According to De Lange et al. (2008), sapropel formation was initiated at ca $9770 \pm 350{ }^{14} \mathrm{C}$ yr BP and ended at $c a 5710 \pm$ $440{ }^{14} \mathrm{C}$ yr вP. However, depending on the proxies measured $\left(\delta^{18} \mathrm{O}\right.$ on G. ruber, $\mathrm{Ba} / \mathrm{Al}$ and $\mathrm{Mn} / \mathrm{Al}$ ratios), the onset and the end of sapropel formation vary by up to 2000 years between the 18 cores analysed; the above cited ages being mean values. Sapropel formation was due to high fluxes of organic matter and to its preservation by lowoxygen bottom waters. Both conditions were linked to modified circulation patterns in the Mediterranean following fresh water input from the Nile River, itself dependent on orbitally controlled climate changes over north-eastern Africa (Cramp \& O’Sullivan, 1999).

Lake sediments have a good potential to record environmental changes with a high, even annual time resolution. For example, in the Triassic Lockatong Formation of the Newark basin, Olsen (1984) found that lake-level fluctuated in tune with the precession cycle, and that the varves preserved in the anoxic sediment accumulated with an average of $0 \cdot 24 \mathrm{~mm}_{\text {year }}{ }^{-1}$.

On shallow carbonate platforms, sedimentation is all but continuous (Goldhammer et al., 1993; Sadler, 1994; Strasser et al., 1999). Emersion during lows of relative sea-level leads to non-deposition and erosion (Fig. 14), ecological factors cause changes in organic carbonate production, and currents and waves redistribute the sediment particles. Furthermore, water depth and sea-floor morphology induce strong lateral variability of facies, making time correlation based on lithology difficult. The best chance to obtain a certain homogenization of the depositional environments is during maximum-flooding conditions, at the turn-around between retrogradation and progradation, when maximum water depth is attained over the entire platform. However, even then high sediment production can outpace sea-level rise and keep the sea floor at very shallow depths (Kendall \& Schlager, 1981; Colombié \& Strasser, 2005), which again induces facies variability. Precise dating and correlation tools are more difficult to come by than in deep-water sediments: biostratigraphically valuable pelagic fossils are rare, compartmentalized water masses may acquire different geochemical compositions, and early fresh water diagenesis may alter the original geochemical signature. Again, it is during maximum-flooding conditions when there is the best

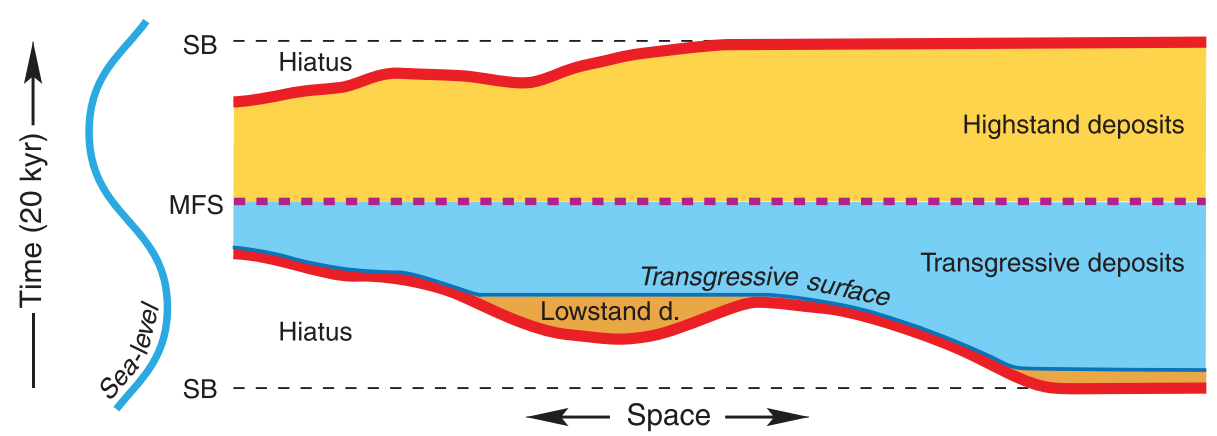

Fig. 14. Influence of platform morphology on the synchronicity of sequence boundaries, transgressive surfaces and maximum-flooding surfaces throughout a $20 \mathrm{kyr}$ sea-level cycle. On the shallow platform, lowstand deposits are commonly absent or confined to depressions. The dashed lines indicate the theoretical positions of the sequence boundaries and the maximum-flooding surface. 
chance that pelagic fauna is washed onto the platform and the water masses above the platform connect with the open ocean. Sequence boundaries are likely to be diachronous if they are erosive and may represent significant time gaps if there was no sedimentation due to emersion. Transgressive surfaces encroach through time over a preexisting morphology and may be erosive: consequently, they are not isochronous unless they result from instant flooding behind a barrier that has been overcome (Fig. 14).

If there is evidence that the observed depositional sequences were formed in tune with orbitally controlled sea-level fluctuations, then, in the best case, a time resolution of $20 \mathrm{kyr}$ can be obtained. Higher (sub-Milankovitch) frequencies have been detected by Zühlke (2004) in the Triassic Latemar platform in northern Italy, but their origins and durations are speculative. If it is furthermore assumed that orbitally induced sealevel changes were more or less symmetrical in the Late Jurassic (see above) and that subsidence was constant, the fastest sea-level rise is expected to occur in the middle of a $20 \mathrm{kyr}$ sea-level cycle (Fig. 10). If the maximum-flooding surface or an interval with a relatively deep and/or openmarine facies can be defined, then a time resolution even higher than $20 \mathrm{kyr}$ can be obtained. This resolution, however, strongly depends on how the maximum flooding is recorded. Its physical expression may be shifted through time depending on sedimentation rate and platform morphology (Catuneanu et al., 1998). Figure 15 summarizes the cases where facies show a gradual deepening then shallowing trend but no surface is developed (maximum-flooding zone), where sedimentation is continuous but a surface and/or rapid facies change is seen (maximumflooding surface), and where there is condensation due to no or strongly reduced sedimentation (condensed section, with or without development of a surface). When correlating the same elementary sequence across the platform, synchronicity can thus be defined at the level of a $20 \mathrm{kyr}$ interval or at the level of subdivisions of this interval, but without being able to attribute exact durations to these subdivisions (see also Fig. 13).

The rates of relative sea-level rise and fall depend on the amplitude of the corresponding $20 \mathrm{kyr}$ eustatic sea-level cycle and on the subsidence rate, and can be estimated only with large error margins. Nevertheless, from the reconstruction in Fig. 10, it is suggested that eustatic sealevel rise was slower by a factor 10 when compared to today's value $\left(30 \mathrm{~cm} \mathrm{kyr}^{-1}\right.$ versus $310 \mathrm{~cm} \mathrm{kyr}^{-1}$ on the global average from 1993 to 2003; IPCC, 2007). This comparison of course is biased because the amplitudes of high-frequency eustatic sea-level changes under greenhouse conditions, such as in the Late Jurassic, were much smaller than under icehouse conditions, such as in the Quaternary and today. However, this bias can be reduced by comparing only small portions of a sea-level cycle (Strasser \& Samankassou, 2003). For example, the sea-level curve reconstructed for Florida, the Bahamas and the Caribbean by Toscano \& Macintyre (2003) implies average rates of sea-level rise of $520 \mathrm{~cm} \mathrm{kyr}^{-1}$ for the period between $10 \cdot 6$ and $7 \cdot 7 \mathrm{ka}$ cal BP, $147 \mathrm{~cm} \mathrm{kyr}^{-1}$ between $7 \cdot 7$ and $2 \mathrm{ka}$, and $93 \mathrm{~cm} \mathrm{kyr}^{-1}$ between 2 and $0 \cdot 4 \mathrm{ka}$.

In the case of the studied Jura platform, the best results concerning time resolution are obtained by the interpretation of high-frequency sea-level fluctuations (Fig. 16). Autocyclically formed facies changes show no discernible pattern, although they may have been indirectly controlled by sea-level: for example, tidal-flat progradation or lateral migration of sand shoals may be more pronounced during early transgressive and late highstand conditions. Storm deposits show no systematic distribution within a $20 \mathrm{kyr}$ cycle.

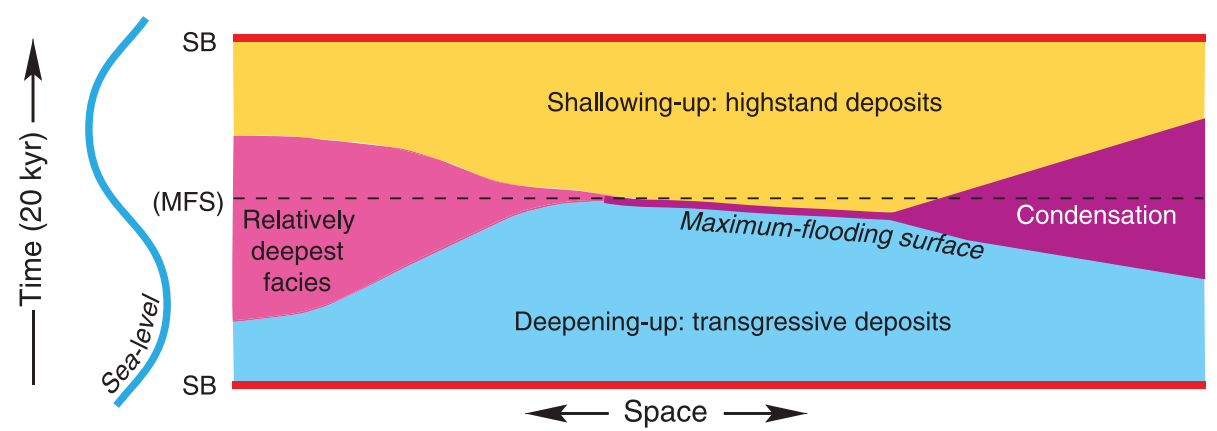

Fig. 15. Different expressions of maximum-flooding conditions within a 20 kyr sequence. The dashed line indicates the position of the theoretical maximum-flooding surface (MFS). It is assumed that there are no hiatuses at the sequence boundaries (SB). For discussion see text. 


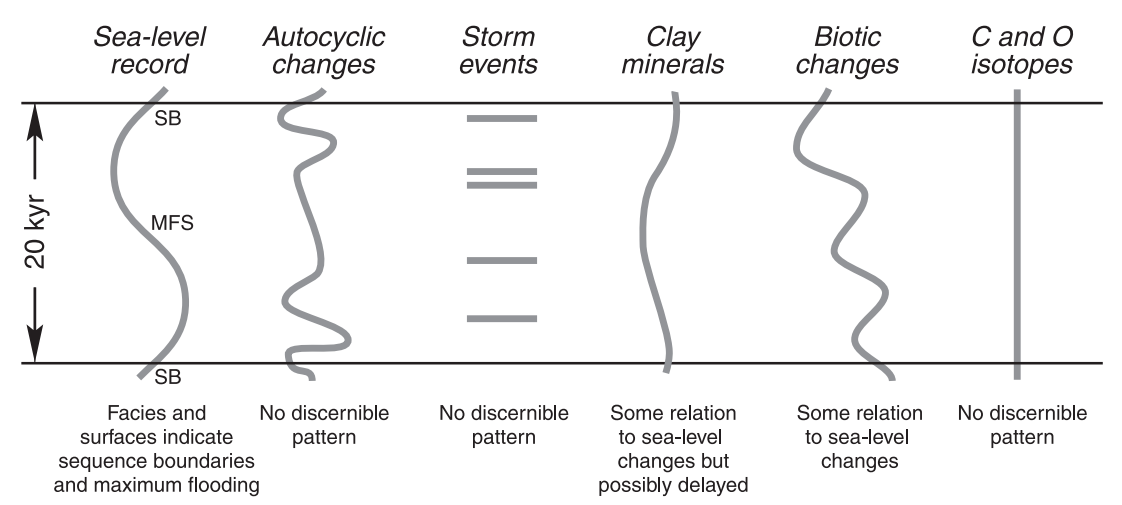

Fig. 16. Different potentials for recording environmental changes in a shallow-water, carbonate-dominated elementary sequence corresponding to the $20 \mathrm{kyr}$ precession cycle. For discussion see text. SB, sequence boundary; MFS, maximum-flooding surface.

It can be imagined that storm intensity increased with increasing sea-surface temperature as it does today (Emanuel, 2005), but it is not possible to demonstrate this in the sections of the Swiss Jura where the fragmentary record of tempestites does not allow a detailed reconstruction of intensities. Clay minerals show some relation to sea-level because of the transport processes but the climate signal they carry may be delayed through the long transit from the hinterland to the study area. Biotic changes depend on a multitude of factors (for example, water energy, water temperature, water chemistry, turbidity, nutrient level, substrate and inter-species relationships) and, therefore, have a complex relationship with sea-level changes. In addition, time-averaging in the sediment makes it difficult to attribute an exact timing. Finally, the record of changes in $\delta^{13} \mathrm{C}$ and $\delta^{18} \mathrm{O}$ is not precise enough at the level of a $20 \mathrm{kyr}$ sequence due to time averaging in the sediment and diagenetic modifications.

\section{CONCLUSIONS}

This study demonstrates that shallow carbonate platforms are very sensitive to environmental changes but that it is difficult to interpret the ancient sedimentary record with a high-enough time resolution to permit direct and quantitative comparisons with today's global changes. Major challenges are establishing a narrow time framework within which the record of environmental changes can be interpreted and their rates evaluated, and correlating between sections and study areas in order to estimate to which degree the changes were synchronous on a regional or global scale.

\section{Potential}

1 If a cyclostratigraphical framework can be established, a time resolution of as high as $20 \mathrm{kyr}$ may be obtained.

2 If a depositional sequence can be attributed to a $20 \mathrm{kyr}$ orbital cycle, and if a high-resolution sequence-stratigraphic analysis allows for subdivision of the sequence, the time resolution becomes even higher.

3 If a $20 \mathrm{kyr}$ sequence and its sequence-stratigraphic elements can be correlated over wide parts of the platform, synchronicity can be evaluated within a few thousand years in the best case.

4 This time resolution becomes comparable to that of the Pleistocene and Holocene where climate, oceanic, biological and sedimentological processes are better known and can be better quantified.

\section{Limitations}

1 It is often difficult to establish an unequivocal cyclostratigraphical framework in carbonate platform sections where autocyclic processes were active and differential subsidence may have distorted the signal of high-frequency, orbitally controlled sea-level changes.

2 In subtidally deposited $20 \mathrm{kyr}$ sequences with homogeneous facies it may be difficult to recognize diagnostic sequence-stratigraphic elements.

3 Due to lateral facies variability and variable sedimentation rates it may be difficult to confidently correlate sequence-stratigraphic intervals and surfaces between sections. 
4 Time-averaging through bioturbation and storm reworking, and diagenesis, commonly modify the original record of environmental changes.

5 Speeds of processes can be evaluated only as an average over the time span obtained by cyclostratigraphy and high-resolution sequence stratigraphy.

\section{From local to regional to global}

1 Unequivocal correlation of $20 \mathrm{kyr}$ sequences is sometimes difficult, even over short distances.

2 Even if surfaces can be walked out, it is impossible to evaluate whether a lithological surface is also an isochrone.

3 Correlations at regional or global scale, from one carbonate platform system to the other, must be confirmed by biostratigraphy, chemostratigraphy and/or magnetostratigraphy and, consequently, the high time resolution becomes more difficult to obtain.

4 The correlation of contemporaneous $20 \mathrm{kyr}$ sequences around the globe is hampered by the lack of precise-enough stratigraphical tools and, consequently, it cannot be confirmed whether the environmental changes observed in the Swiss Jura were of local, regional or global extent.

5 If an environmental change recorded on the Jura platform was indeed of global extent, it cannot be said to what extent it was synchronous with the records in other locations.

\section{From the past to the present}

1 On the Oxfordian platform in the Jura Mountains, a time resolution of $20 \mathrm{kyr}$ is possible, but the synchronicity of surfaces and facies changes reflecting environmental changes can be evaluated only approximately by estimating the time distribution within a $20 \mathrm{kyr}$ sequence.

2 Today, significant global environmental changes happen within a few tens of years.

3 From the studied sedimentary record, it can only be said that environmental changes happened within a time interval of a few thousand years, but very rapid reactions to environmental change could be obtained locally if a threshold was passed, such as the flooding of a barrier.

4 The Oxfordian coral reefs had several phases of growth and demise within a $20 \mathrm{kyr}$ time interval but a direct correlation with short-term sea-level and climate changes cannot be established.
5 Today, a general demise of shallow-water coral reefs is observed.

6 Although the exact rates and amplitudes of environmental changes in the past remain elusive, their sedimentary and palaeoecological record on shallow carbonate platforms can provide examples of possible future consequences of the rapid evolution of today.

\section{ACKNOWLEDGEMENTS}

We thank Stephen Lokier for inviting us to write this contribution and for the editorial help. We also thank Telm Bover Arnal for his helpful comments on a first version of the manuscript, and Marc Aurell and Adrian Immenhauser for their thorough and constructive reviews. The financial support of the Swiss National Science Foundation (project No. 20-121545.08) is gratefully acknowledged.

\section{REFERENCES}

Abbink, O., Targarona, J., Brinkhuis, H. and Visscher, H. (2001) Late Jurassic to earliest Cretaceous palaeoclimatic evolution of the southern North Sea. Global Planet. Change, 30, 231-256.

Allan, J.R. and Matthews, R.K. (1982) Isotope signatures associated with early meteoric diagenesis. Sedimentology, 29, 797-817.

Allenbach, R.P. (2001) Synsedimentary tectonics in an epicontinental sea: a new interpretation of the Oxfordian basins of northern Switzerland. Eclogae Geol. Helv., 94, 265-287.

Aurell, M. and Bádenas, B. (2004) Facies and depositional sequence evolution controlled by high-frequency sea-level changes in a shallow-water carbonate ramp (late Kimmeridgian, NE Spain). Geol. Mag., 141, 717-733.

Bartolini, A., Baumgartner, P.O. and Hunziker, J. (1996) Middle and Late Jurassic carbon stable-isotope stratigraphy and radiolarite sedimentation of the Umbria-Marche Basin (Central Italy). Eclogae Geol. Helv., 89, 811-844.

Bathurst, R.G.C. (1987) Diagenetically enhanced bedding in argillaceous platform limestones: stratified cementation and selective compaction. Sedimentology, 34, 749-778.

Beerling, D.J., Lomas, M.R. and Gröcke, D.R. (2002) On the nature of methane gas-hydrate dissociation during the Toarcian and Aptian oceanic anoxic events. Am. J. Sci., 302, 28-49.

Berger, A., Loutre, M.F. and Dehant, V. (1989) Astronomical frequencies for pre-Quaternary palaeoclimate studies. Terra Nova, 1, 474-479.

Bessat, F. and Buigues, D. (2001) Two centuries of variation in coral growth in a massive Porites colony from Moorea (French Polynesia): a response of ocean-atmosphere variability from south central Pacific. Palaeogeogr. Palaeoclimatol. Palaeoecol., 175, 381-392.

Brandt, M.E. (2009) The effect of species and colony size on the bleaching response of reef-building corals in the Florida 
Keys during the 2005 mass bleaching event. Coral Reefs, 28, 911-924.

Burgess, P.M. (2006) The signal and the noise: forward modeling of allocyclic and autocyclic processes influencing peritidal carbonate stacking patterns. J. Sed. Res., 76, 962977.

Burgess, P.M. and Wright, V.P. (2003) Numerical forward modeling of carbonate platform dynamics: an evaluation of complexity and completeness in carbonate strata. J. Sed. Res., 73, 637-652.

Carpentier, C., Martin-Garin, B., Lathuilière, B. and Ferry, S. (2006) Correlation of reefal Oxfordian episodes and climatic implications in the eastern Paris Basin (France). Terra Nova, 18, 191-201.

Catuneanu, O., Willis, A.J. and Miall, A.D. (1998) Temporal significance of sequence boundaries. Sed. Geol., 121, 157178.

Chamley, H. (1989) Clay Sedimentology. Springer-Verlag, Berlin, 623 pp.

Cherns, L., Wheeley, J.R. and Wright, V.P. (2008) Taphonomic windows and molluscan preservation. Palaeogeogr. Palaeoclimatol. Palaeoecol., 270, 220-229.

Clari, P.A., Dela Pierre, F. and Martire, L. (1995) Discontinuities in carbonate successions: identification, interpretation and classification of some Italian examples. Sed. Geol., 100, 97-121.

Colombié, C. and Strasser, A. (2005) Facies, cycles, and controls on the evolution of a keep-up carbonate platform (Kimmeridgian, Swiss Jura). Sedimentology, 52, 1207-1227.

Colombié, C., Lécuyer, C. and Strasser, A. (2010) Carbon-and oxygen-isotope records of palaeoenvironmental and carbonate production changes in shallow-marine carbonates (Kimmeridgian, Swiss Jura). Geol. Mag., first view, 1-21. doi: 10.1017/S0016756810000518.

Cramp, A. and O'Sullivan, G. (1999) Neogene sapropels in the Mediterranean: a review. Marine Geol., 153, 11-28.

Crevello, P.D. (1991) High-frequency carbonate cycles and stacking patterns: interplay of orbital forcing and subsidence on Lower Jurassic rift platforms, High Atlas, Morocco. In: Sedimentary Modeling: Computer Simulations and Methods for Improved Parameter Definition (Eds. E.K. Franseen, W.L. Watney, C.G.St.C. Kendall and W. Ross), Mem. Kansas Geol. Surv., 233, 207-230.

Crowley, T.J. (2000) Causes of climate change over the past 1000 years. Science, 289, 270-277.

Curtis, C.D. (1990) Aspects of climate influence on the clay mineralogy and geochemistry of soils, paleosols and clastic sedimentary rocks. J. Geol. Soc. London, 147, 351-357.

Davies, D.J., Powell, E.N. and Stanton, R.J.J. (1989) Relative rates of shell dissolution and net sediment accumulation - a commentary: can shell beds form by the gradual accumulation of biogenic debris on the sea floor? Lethaia, 22, 207212.

De Lange, G.J., Thomson, J., Reitz, A., Slomp, C.P., Principato, M.S., Erba, E. and Corselli, C. (2008) Synchronous basinwide formation and redox-controlled preservation of a Mediterranean sapropel. Nat. Geosci., 1, 606-610.

Deconinck, J.-F. (1993) Clay mineralogy of the Late Tithonian-Berriasian deep-sea carbonates of the Vocontian Trough (SE France): relationships with sequence stratigraphy. Bull. Centres Rech. Explor.-Prod. Elf Aquitaine, 17, 223-234.

Deconinck, J.-F., Beaudoin, B., Chamley, H., Joseph, P. and Raoult, J.-F. (1985) Contrôles tectonique, eustatique et climatique de la sédimentation argileuse du domaine subalpin français au Malm-Crétacé. Rev. Géol. Dyn. Géogr. Phys., 26, 311-320.

Dercourt, J., Ricou, L.E. and Vrielynck, B. (1993) Atlas: Tethys Palaeogeographic Maps. CCGM, Paris.

Dravis, J. (1979) Rapid and widespread generation of recent oolitic hardgrounds on a high energy Bahamian platform, Eleuthera Bank, Bahamas. J. Sed. Petrol., 49, 195-208.

Drummond, C.N. and Wilkinson, B.H. (1993) Carbonate cycle stacking patterns and hierarchies of orbitally forced eustatic sea level change. J. Sed. Petrol., 63, 369-377.

Dunham, R.J. (1962) Classification of carbonate rocks according to depositional texture. AAPG Mem., 1, 108-121.

Dupraz, C. (1999) Paléontologie, paléoecologie et évolution des faciès récifaux de l'Oxfordien Moyen-Supérieur (Jura suisse et français). GeoFocus, 2, 247 pp.

Dupraz, C. and Strasser, A. (2002) Nutritional modes in coralmicrobialite reefs (Jurassic, Oxfordian, Switzerland): evolution of trophic structure as a response to environmental change. Palaios, 17, 449-471.

Emanuel, K. (2005) Increasing destructiveness of tropical cyclones over the past 30 years. Nature, 436, 686-688.

Enay, R., Cariou, E., Debrand Passard, S., Menot, J.-C. and Rioult, M. (1980) Middle-Oxfordian. In: Synthèse paléogéographique du Jurassique français (Eds. R. Enay and C. Mangold). Doc. Lab. Géol. Fac. Sci. Lyon, 5, 181-184.

Enos, P. (1991) Sedimentary parameters for computer modeling. In: Sedimentary Modeling: Computer Simulations and Methods for Improved Parameter Definition (Eds. E.K. Franseen, W.L. Watney, C.G.St.C. Kendall and W. Ross). Mem. Kansas Geol. Surv., 233, 63-99.

Eyles, N. (1993) Earth's glacial record and its tectonic setting. Earth-Sci. Rev., 35, 1-248.

Fairbridge, R.W. (1976) Convergence of evidence on climatic change and ice ages. Ann. NY Acad. Sci., 91, 542-579.

Flessa, K.W., Cutler, A.H. and Meldahl, K.H. (1993) Time and taphonomy: quantitative estimates of time-averaging and stratigraphic disorder in a shallow marine habitat. Paleobiology, 19, 266-286.

Frakes, L.A., Francis, J.E. and Syktus, J.I. (1992) Climate Modes of the Phanerozoic. Cambridge Univ Press, Cambridge, $274 \mathrm{pp}$.

Ginsburg, R.N. (1971) Landward movement of carbonate mud: new model for regressive cycles in carbonates (abstract). AAPG Bull., 55, 340.

Goff, J.A., Allison, M.A. and Gulick, S.P.S. (2010) Offshore transport of sediment during cyclonic storms: Hurricane Ike (2008), Texas Gulf Coast, USA. Geology, 38, 351354.

Goldhammer, R.K. (1997) Compaction and decompaction algorithms for sedimentary carbonates. J. Sed. Petrol., 67, 26-35.

Goldhammer, R.K., Lehmann, P.J. and Dunn, P.A. (1993) The origin of high-frequency platform carbonate cycles and third-order sequences (Lower Ordovician El Paso Gp, west Texas): constraints from outcrop data and stratigraphic modeling. J. Sed. Petrol., 63, 318-359.

Gornitz, V., Lebedeff, S. and Hansen, J. (1982) Global sea-level trend in the past century. Science, 215, 1611-1614.

Gygi, R.A. (1995) Datierung von Seichtwassersedimenten des Späten Jura in der Nordwestschweiz mit Ammoniten. Eclogae Geol. Helv., 88, 1-58.

Gygi, R.A. (2000) Integrated stratigraphy of the Oxfordian and Kimmeridgian (Late Jurassic) in northern Switzerland and adjacent southern Germany. Mem. Swiss Acad. Sci., 104, 152. 
Gygi, R.A. and Persoz, F. (1986) Mineralostratigraphy, litho- and biostratigraphy combined in correlation of the Oxfordian (Late Jurassic) formations of the Swiss Jura range. Eclogae Geol. Helv., 79, 385-454.

Gygi, R.A., Coe, A.L. and Vail, P.R. (1998) Sequence stratigraphy of the Oxfordian and Kimmeridgian stages (Late Jurassic) in northern Switzerland. SEPM Spec. Publ., 60, 527-544.

Halley, R.B. and Harris, P.M. (1979) Fresh-water cementation of a 1,000-year-old oolite. J. Sed. Petrol., 49, 969-988.

Hardenbol, J., Thierry, J., Farley, M.B., Jacquin, T., De Graciansky, P.-C. and Vail, P.R. (1998) Jurassic sequence chronostratigraphy. SEPM Spec. Publ., 60. Chart.

Hillgärtner, H. (1998) Discontinuity surfaces on a shallowmarine carbonate platform (Berriasian-Valanginian, France and Switzerland). J. Sed. Res., 68, 1093-1108.

Hillgärtner, H., Dupraz, C. and Hug, W. (2001) Microbially induced cementation of carbonate sands: are micritic meniscus cements good indicators of vadose diagenesis? Sedimentology, 48, 117-131.

Hug, W. (2003) Sequenzielle Faziesentwicklung der Karbonatplattform des Schweizer Jura im Späten Oxford und frühesten Kimmeridge. GeoFocus, 7, 156 pp.

Immenhauser, A. (2009) Estimating palaeo-water depth from the physical rock record. Earth-Sci. Rev., 96, 107-139.

Immenhauser, A., Della Porta, G. and Kenter, J.A.M. (2003) An alternative model for positive shifts in shallowmarine carbonate $\delta^{13} \mathrm{C}$ and $\delta^{18} \mathrm{O}$. Sedimentology, 50, 953959.

Immenhauser, A., Hillgärtner, H. and van Betum, E. (2005) Microbial-foraminiferal episodes in the Early Aptian of the southern Tethyan margin: ecological significance and possible relation to oceanic anoxic event 1a. Sedimentology, 52, 77-99.

IPCC (2007) Summary for policymakers. In: Climate Change 2007: The Physical Science Basis. Contribution of Working Group I to the Fourth Assessment Report of the Intergovernmental Panel on Climate Change (Eds. S. Solomon, D. Qin, M. Manning, Z. Chen, M. Marquis, K.B. Averyt, M. Tignor and H.L. Miller). 18pp. Cambridge University Press, Cambridge.

Jacobs, D.K. and Sahagian, D.L. (1993) Climate-induced fluctuations in sea level during non-glacial times. Nature, 361, 710-712.

Joachimski, M.M. (1994) Subaerial exposure and deposition of shallowing upward sequences: evidence from stable isotopes of Purbeckian peritidal carbonates (basal Cretaceous), Swiss and French Jura Mountains. Sedimentology, 41, 805824.

Jokiel, P.L., Rodgers, K.S., Kuffner, I.B., Andersson, A.J., Cox, E.F. and Mackenzie, F.T. (2008) Ocean acidification and calcifying reef organisms: a mesocosm investigation. Coral Reefs, 27, 473-483.

Kendall, C.G.St.C. and Schlager, W. (1981) Carbonates and relative changes in sea level. Marine Geol., 44, 181-212.

Kidwell, S.M., Best, M.M.R. and Kaufman, D.S. (2005) Taphonomic trade-offs in tropical marine death assemblages: differential time-averaging, shell loss, and probable bias in siliciclastic vs. carbonate facies. Geology, 33, 729732 .

Kübler, B. (1990) "Cristallinité" de l'illite et mixed-layers: brève révision. Schweiz. Mineral. Petrogr. Mitt., 70, 89-93.

Langreis, C.G., Krijgsman, W., Muttoni, G. and Menning, M. (2010) Magnetostratigraphy - concepts, definitions, and applications. Newsl. Stratigr., 43, 207-234.
Louis-Schmid, B. (2006) Feedback Mechanisms between Carbon Cycling, Climate and Oceanography. Unpublished $\mathrm{PhD}$ thesis, ETH Zurich, Switzerland, 132 pp.

Louis-Schmid, B., Rais, P., Bernasconi, S.M., Pellenard, P., Collin, P.-Y. and Weissert, H. (2007) Detailed record of the mid-Oxfordian (Late Jurassic) positive carbon-isotope excursion in two hemipelagic sections (France and Switzerland): a plate-tectonic trigger? Palaeogeogr. Palaeoclimatol. Palaeoecol., 248, 459-472.

Matthews, M.D. and Perlmutter, M.A. (1994) Global cyclostratigraphy: an application to the Eocene Green River Basin. IAS Spec. Publ., 19, 459-481.

McCook, L.J. (1999) Macroalgae, nutrients and phase shifts on coral reefs: scientific issues and management consequences for the Great Barrier Reef. Coral Reefs, 18, 357-367.

Méhay, S., Keller, C., Bernasconi, S.M., Weissert, H., Erba, E., Bottini, C. and Hochuli, P.A. (2009) A volcanic $\mathrm{CO}_{2}$ pulse triggered the Cretaceous Oceanic Anoxic Event 1a and a biocalcification crisis. Geology, 37, 819-822.

Menegatti, A.P., Weissert, H., Brown, S., Tyson, R.V., Farrimond, P., Strasser, A. and Caron, M. (1998) High-resolution $\delta^{13} \mathrm{C}$ stratigraphy through the early Aptian "Livello Selli" of the Alpine Tethys. Paleoceanography, 13, 530-545.

Moore, C.H. (1989) Carbonate Diagenesis and Porosity. Dev. Sedimentol., 46, $338 \mathrm{pp}$.

Olsen, P.E. (1984) Periodicity of lake-level cycles in the Late Triassic Lockatong Formation of the Newark basin (Newark Supergroup, New Jersey and Pennsylvania). In: Milankovitch and Climate, Understanding the Response to Orbital Forcing (Eds. A.L. Berger, J. Imbrie, J. Hays, G. Kukla and B. Saltzman). NATO ASI Series C, 126, 129-146.

Padden, M., Weissert, H. and de Rafélis, M. (2001) Evidence for Late Jurassic release of methane from gas hydrate. Geology, 29, 223-226.

Patterson, W.P. and Walter, L.M. (1994) Depletion of ${ }^{13} \mathrm{C}$ in seawater $\Sigma \mathrm{CO}_{2}$ on modern carbonate platforms: significance for the carbon isotopic record of carbonates. Geology, 22, 885-888.

Peñaflor, E.L., Skirving, W.J., Strong, A.E., Heron, S.F. and David, L.T. (2009) Sea-surface temperature and thermal stress in the Coral Triangle over the past two decades. Coral Reefs, 28, 841-850.

Pittet, B. (1996) Contrôles climatiques, eustatiques et tectoniques sur des systèmes mixtes carbonates-siliciclastiques de plate-forme: exemples de l'Oxfordien (Jura suisse, Normandie, Espagne). Unpublished $\mathrm{PhD}$ thesis, University of Fribourg, Fribourg, Switzerland, $258 \mathrm{pp}$.

Pittet, B. and Strasser, A. (1998) Long-distance correlations by sequence stratigraphy and cyclostratigraphy: examples and implications (Oxfordian from the Swiss Jura, Spain, and Normandy). Geol. Rundschau, 86, 852-874.

Plunkett, J.M. (1997) Early Diagenesis of Shallow Platform Carbonates in the Oxfordian of the Swiss Jura Mountains. Unpublished PhD thesis, University of Fribourg, Fribourg, Switzerland, $155 \mathrm{pp}$.

Pratt, B.R. and James, N.P. (1986) The St George Group (Lower Ordovician) of western Newfoundland: tidal flat island model for carbonate sedimentation in shallow epeiric seas. Sedimentology, 33, 313-343.

Price, G.D. (1999) The evidence and implications of polar ice during the Mesozoic. Earth-Sci. Rev., 48, 183-210.

Ramajo, J. and Aurell, M. (2008) Long-term Callovian-Oxfordian sea-level changes and sedimentation in the Iberian carbonate platform (Jurassic, Spain): possible eustatic implications. Basin Res., 20, 163-184. 
Read, J.F. (1995) Overview of carbonate platform sequences, cycle stratigraphy and reservoirs in greenhouse and icehouse worlds. SEPM Short Course, 35, 1-102.

Retallack, G.J. (2001) Soils of the Past - An Introduction to Paleopedology, 2nd edn. Blackwell, Oxford, $404 \mathrm{pp}$.

Sadler, P.M. (1994) The expected duration of upward-shallowing peritidal carbonate cycles and their terminal hiatuses. Geol. Soc. Am. Bull., 106, 791-802.

Satterley, A.K. (1996) The interpretation of cyclic successions of the Middle and Upper Triassic of the Northern and Southern Alps. Earth-Sci. Rev., 40, 181-207.

Savrda, C.E. and Bottjer, D.J. (1988) Limestone concretion growth documented by trace-fossil relations. Geology, 16, 908-911.

Schlager, W. (1993) Accommodation and supply - a dual control on stratigraphic sequences. Sed. Geol., 86, 111136.

Schlagintweit, F., Bover-Arnal, T. and Salas, R. (2010) New insights into Lithocodium aggregatum Elliott 1956 and Bacinella irregularis Radoičić 1959 (Late Jurassic-Lower Cretaceous): two ulvophycean grreen algae (?Order Ulotrichales) with a heteromorphic life cycle (epilithic/euendolithic). Facies, 56, 509-547.

Schoene, B., Guex, J., Bartolini, A., Schaltegger, U. and Blackburn, T.J. (2010) Correlating the end-Triassic mass extinction and flood basalt volcanism at the $100 \mathrm{ka}$ level. Geology, 38, 387-390.

Schulz, M. and Schäfer-Neth, C. (1998) Translating Milankovitch climate forcing into eustatic fluctuations via thermal deep water expansion: a conceptual link. Terra Nova, $\mathbf{9}$, 228-231.

Servonnat, J., Yiou, P., Khodri, M., Swingedouw, D. and Denvil, S. (2010) Influence of solar variability, $\mathrm{CO}_{2}$ and orbital forcing between 1000 and $1850 \mathrm{AD}$ in the IPSLCM4 model. Clim. Past, 6, 445-460.

Shinn, E.A. and Robbin, D.M. (1983) Mechanical and chemical compaction in fine-grained shallow-water limestones. J. Sed. Petrol., 53, 595-618.

Smith, L.D., Gilmour, J.P. and Heyward, A.J. (2008) Resilience of coral communities on an isolated system of reefs following catastrophic mass bleaching. Coral Reefs, 27, 197205.

Stienne, N. (2010) Paléoécologie et taphonomie comparative en milieux carbonatés peu profonds (Oxfordien du Jura Suisse et Holocène du Belize). GeoFocus, 22, 248 pp.

Strasser, A. (2007) Astronomical time scale for the Middle Oxfordian to Late Kimmeridgian in the Swiss and French Jura Mountains. Swiss J. Geosci., 100, 407-429.

Strasser, A. and Samankassou, E. (2003) Carbonate sedimentation rates today and in the past: Holocene of Florida Bay, Bahamas, and Bermuda vs. Upper Jurassic and Lower Cretaceous of the Jura Mountains (Switzerland and France). Geologica Croatica, 56, 1-18.

Strasser, A. and Védrine, S. (2009) Controls on facies mosaics of carbonate platforms: a case study from the Oxfordian of the Swiss Jura. IAS Spec. Publ., 41, 199-213.

Strasser, A., Pittet, B., Hillgärtner, H. and Pasquier, J.-B. (1999) Depositional sequences in shallow carbonate-dominated sedimentary systems: concepts for a high-resolution analysis. Sed. Geol., 128, 201-221.

Strasser, A., Hillgärtner, H. and Pasquier, J.-B. (2004) Cyclostratigraphic timing of sedimentary processes: an example from the Berriasian of the Swiss and French Jura Mountains. SEPM Spec. Publ., 81, 135-151.
Strasser, A., Hilgen, F.J. and Heckel, P.H. (2006) Cyclostratigraphy - concepts, definitions, and applications. Newsl. Stratigr., 42, 75-114.

Thierry, J. (2000) Early Kimmeridgian (146-144 Ma). In: Atlas Peri-Tethys (Eds. J. Dercourt, M. Gaetani, B. Vrielynck, E. Barrier, B. Biju-Duval, M.F. Brunet, J.P. Cadet, S. Crasquin and M. Sandulescu), Map 10. CCGM/CGMW, Paris.

Thiry, M. (2000) Palaeoclimatic interpretation of clay minerals in marine deposits: an outlook from the continental origin. Earth-Sci. Rev., 49, 201-221.

Toscano, M.A. and Macintyre, I.G. (2003) Corrected western Atlantic sea-level curve for the last 11,000 years based on calibrated ${ }^{14} \mathrm{C}$ dates from Acropora palmata framework and intertidal mangrove peat. Coral Reefs, 22, 257-270.

Trümpy, R. (1980) Geology of Switzerland, a Guide-Book. Part A: An Outline of the Geology of Switzerland. Wepf \& Co., Basel, 104 pp.

Vail, P.R., Audemard, F., Bowman, S.A., Eisner, P.N. and Perez-Cruz, C. (1991) The stratigraphic signatures of tectonics, eustasy and sedimentology - an overview. In: Cycles and Events in Stratigraphy (Eds. G. Einsele, W. Ricken and A. Seilacher), pp. 617-659. Springer-Verlag, Heidelberg.

Van Breugel, Y., Schouten, S., Tsikos, H., Erba, E., Price, G.D. and Sinninghe Damsté, J.S. (2007) Synchronous marine and terrestrial biomarkers at the onset of the early Aptian oceanic anoxic event 1a: evidence for the release of ${ }^{13} \mathrm{C}$-depleted carbon into the atmosphere. Paleoceanography, 22, PA1210.

Van der Kooij, B., Immenhauser, A., Csoma, A., Bahamonde, J. and Steuber, T. (2009) Spatial geochemistry of a Carboniferous platform-margin-to-basin transect: balancing environmental and diagenetic factors. Sed. Geol., 219, 136-150.

Védrine, S. (2007) High-frequency palaeoenvironmental changes in mixed carbonate-siliciclastic sedimentary systems (Late Oxfordian, Switzerland, France, and southern Germany). GeoFocus, 19, 216.

Védrine, S. (2008) Co-occurrence of the foraminifer Mohlerina basiliensis with Bacinella-Lithocodium oncoids: palaeoenvironmental and palaeoecological implications (Late Oxfordian, Swiss Jura). J. Micropal., 27, 35-44.

Védrine, S., Strasser, A. and Hug, W. (2007) Oncoid growth and distribution controlled by sea-level fluctuations and climate (Late Oxfordian, Swiss Jura Mountains). Facies, 53, 535-552.

Weissert, H. and Erba, E. (2004) Volcanism, $\mathrm{CO}_{2}$ and palaeoclimate: a Late Jurassic-Early Cretaceous carbon and oxygen isotope record. J. Geol. Soc. London, 161, 695-702.

Weissert, H., Joachimski, M. and Sarnthein, M. (2008) Chemostratigraphy. Newsl. Stratigr., 42, 145-179.

Wildi, W., Funk, H., Loup, B., Amato, E. and Huggenberger, P. (1989) Mesozoic subsidence history of the European marginal shelves of the Alpine Tethys (Helvetic realm, Swiss Plateau and Jura). Eclogae Geol. Helv., 82, 817-840.

Ziegler, P.A. (1990) Geological Atlas of Western and Central Europe. Shell International Petroleum Maatschappij, The Hague, 233 pp.

Zühlke, R. (2004) Integrated cyclostratigraphy of a model Mesozoic carbonate platform - the Latemar (Middle Triassic, Italy). SEPM Spec. Publ., 81, 183-211. 